\title{
The immunological potency and therapeutic potential of a prototype dual vaccine against influenza and Alzheimer's disease
}

\author{
Hayk Davtyan 1,2, Anahit Ghochikyan', Richard Cadagan³, Dmitriy Zamarin³, Irina Petrushina², Nina Movsesyan², \\ Luis Martinez-Sobrido ${ }^{4}$, Randy A Albrechtt ${ }^{3,5}$, Adolfo García-Sastre ${ }^{3,5,6}$ and Michael G Agadjanyan 1,2*
}

\begin{abstract}
Background: Numerous pre-clinical studies and clinical trials demonstrated that induction of antibodies to the $\beta$ amyloid peptide of 42 residues ( $A \beta_{42}$ ) elicits therapeutic effects in Alzheimer's disease (AD). However, an active vaccination strategy based on full length $A \beta_{42}$ is currently hampered by elicitation of $T$ cell pathological autoreactivity. We attempt to improve vaccine efficacy by creating a novel chimeric flu vaccine expressing the small immunodominant $B$ cell epitope of $A \beta_{42}$. We hypothesized that in elderly people with pre-existing memory Th cells specific to influenza this dual vaccine will simultaneously boost anti-influenza immunity and induce production of therapeutically active anti-A $\beta$ antibodies.

Methods: Plasmid-based reverse genetics system was used for the rescue of recombinant influenza virus containing immunodominant $B$ cell epitopes of $A \beta_{42}\left(A \beta_{1-7 / 10}\right)$.

Results: Two chimeric flu viruses expressing either 7 or 10 aa of $A \beta_{42}$ (flu-A $\beta_{1-7}$ or flu-A $\beta_{1-10}$ ) were generated and tested in mice as conventional inactivated vaccines. We demonstrated that this dual vaccine induced therapeutically potent anti-A $\beta$ antibodies and anti-influenza antibodies in mice.

Conclusion: We suggest that this strategy might be beneficial for treatment of AD patients as well as for prevention of development of $\mathrm{AD}$ pathology in pre-symptomatic individuals while concurrently boosting immunity against influenza.
\end{abstract}

\section{Introduction}

Alzheimer's disease (AD) is the most common form of dementia in the elderly which is clinically characterized by progressive loss of memory and general cognitive decline. The neuropathological features of AD include neurofibrillary tangles (NFT), deposition of soluble (monomeric, oligomeric) and insoluble fibrillar $A \beta$ (senile plaques) forms, and neuronal loss in affected brain regions [1]. Pre-clinical and clinical trials have revealed that anti-A $\beta$ antibodies are beneficial in clearing $A \beta$ deposits [2-13]. The first clinical trial of active immunization against $A \beta$ was of the vaccine AN 1792, which comprised of fibrillar $A \beta_{42}$ formulated in a strong

\footnotetext{
* Correspondence: magadjanyan@immed.org

'Department of Molecular Immunology, Institute for Molecular Medicine, Huntington Beach, CA 92647, USA

Full list of author information is available at the end of the article
}

Th1-type biasing adjuvant, QS21. Patients treated with this vaccine were suffering mild-to-moderate $\mathrm{AD}$. The trial was halted due to development of meningoencephalitis in some of the patients, which was believed to be associated with anti-A $\beta$ specific $T$ cell immune responses $[8,9,14-16]$. One possible way to avoid these side effects is the replacement of the self- $T$ helper epitope(s) present in the $A \beta_{42}$ peptide by a foreign epitope (s) while leaving self-B cell epitope(s) of $A \beta_{42}$ intact. Another important, but overlooked, result from the AN1792 clinical trial was that the majority of AD patients generated only low titers of anti-A $\beta$ antibodies, and approximately $50 \%$ of the patients failed to produce a measurable antibody response $[12,17]$. The cause of the low anti-A $\beta$ antibody titers and non-responsiveness observed in AN-1792 trial could be due to immune tolerance induced by self- $A \beta_{42}$ antigen. The mammalian

\section{Biomed Central}


immune system normally fails to generate antibodies specific to self-molecules; however, B cell tolerance is not rigorous, while $\mathrm{T}$ cell tolerance is more stringent $[18,19]$. Previously we suggested that replacement of the Th cell epitope of $A \beta_{42}$ by a foreign Th epitope will help to overcome not only $\mathrm{T}$ cell tolerance induced by self antigen, but also side effects caused by autoreactive $\mathrm{T}$ cells. In our previous work we generated peptide- and DNA-based epitope vaccines based on amyloid-specific B-cell epitopes $A \beta_{1-15}$ or $A \beta_{1-11}$ attached to the promiscuous foreign Th epitope pan HLA DR-binding peptide (PADRE) and demonstrated the feasibility of this strategy in wild-type [20-22] and APP/Tg mice [23-25]. In this study we hypothesized that for therapeutic purposes $\mathrm{AD}$ epitope vaccines could be delivered to patients by a conventional viral vaccine [26]. Specifically, chimeric influenza viruses expressing the $B$ cell epitope of $A \beta$ may not only induce anti-viral immunity, but also generate higher titers of anti- $\mathrm{A} \beta$ antibodies in adult individuals with pre-existing influenza virus-specific memory Th cells. Accordingly, we generated and tested for the first time the immunogenicity and protective efficacy of chimeric inactivated flu virus vaccines expressing 1-7 or 1-10 aa of $A \beta_{42}$ (flu-A $\beta_{1-7}$ and flu-A $\beta_{1-10}$ ) in mice and demonstrated that these dual vaccines induced therapeutically potent anti- $\mathrm{A} \beta$ and anti-influenza antibodies.

\section{Materials and methods}

Mice

Female, 5-6 week-old C57Bl/6 mice were obtained from the Jackson Laboratory (MN). All animals were housed in a temperature- and light cycle-controlled animal facility at the Institute for Memory Impairments and Neurological Disorders (MIND), University of California Irvine (UCI). Animal use protocols were approved by the Institutional Animal Care and Use Committee of UCI and were in accordance with the guidelines of the National Institutes of Health.

\section{Generation and purification of chimeric virus}

Figure 1A illustrates the plasmid-based reverse genetic rescue system $[26,27]$ used to generate chimeric influenza A/WSN/33 (H1N1) viruses expressing $B$ cell epitopes $A \beta_{1-10}\left(W S N-A \beta_{1-10}\right)$, or $A \beta_{1-7}\left(W S N-A \beta_{1-7}\right)$ from $A \beta_{42}$. This system includes four protein expression plasmids encoding the three influenza virus polymerase proteins (PB1, PB2 and PA) and nucleoprotein (NP), plus eight transcription plasmids encoding the eight viral gene segments. Sequences encoding B cell epitope of amyloid- $\beta$ were cloned into the HA segment near the receptor binding site. Chimeric and wild-type viruses were rescued in Madin-Darby canine kidney (MDCK)/ $293 \mathrm{~T}$ cell co-cultures, and the identity of the rescued viruses was confirmed by RT-PCR and restriction/ sequence analysis of the HA gene segment containing the engineered foreign sequence as previously described [27]. Chimeric viruses were further grown in embryonated 10 day-old hen eggs. Viruses were purified from allantoic fluid by centrifugation through a $30 \%$ sucrose cushion. Protein concentration in purified virus samples was determined by the Bio-Rad protein assay (Bio-RAD, $\mathrm{CA})$ and the purity of the samples was analyzed by SDS-PAGE (Bio-RAD, CA). The protein bands were visualized by coomassie blue staining.

\section{Western Blotting and Dot Blot Assay}

Presence of $A \beta$ epitope in WSN-A $\beta_{1-10}$ or WSN-A $\beta_{1-7}$ was confirmed by Western blot using anti-A $\beta 20.1$ monoclonal antibody (gift from Dr. Van-Nostrand, Stony Brook University). Influenza proteins NP, HA and M1 were visualized by staining with rabbit polyclonal anti-WSN serum (gift of Drs. Thomas Moran and Peter Palese, Mount Sinai School of Medicine). Western Blot was done as described in [28].

Binding of anti-A $\beta_{1-10}$ sera to different forms of $A \beta_{42}$ peptide was analyzed by Dot Blot assay. Briefly, we applied $1 \mu \mathrm{l}$ of monomeric, oligomeric, or fibrillar forms of $A \beta_{42}$ and irrelevant peptide (100 $\mu \mathrm{M}$ each) to a nitrocellulose membrane as described [24]. After blocking and washing, the membranes were probed with sera of mice immunized with either WSN-A $\beta_{1-10}$ or WSN-WT formalin-inactivated virus vaccines, or with antibodies $6 \mathrm{E} 10$ specific for $\mathrm{A} \beta \mathrm{N}$-terminal region spanning aa 3-8 (1:3000; Covance Inc., NJ) and anti-oligomer A11 (1:500; Sigma-Aldrich, MO). Sera were used at dilution 1:200. The membranes were incubated with appropriate horseradish peroxidase-conjugated anti-mouse or antirabbit (only for A11) antibodies (1:1000; Santa Cruz Biotechnology, Inc., CA). Blots were developed using Luminol reagent (Santa Cruz Biotechnology, Inc., CA) and exposed to HyBlot CL Autoradiography Film (Denville Scientific Inc., NJ).

\section{Immunofluorescence}

Expression of $A \beta$ epitopes by chimeric viruses was analyzed by immunofluorescence of infected cells. Briefly, confluent MDCK monolayers were infected with wildtype (WSN-WT) influenza virus or chimeric viruses WSN-A $\beta_{1-10}$ or $-A \beta_{1-7}$. Twelve hours post-infection cells were washed with PBS, fixed with $1 \%$ paraformaldehyde, permeabilized with $0.1 \%$ Triton X-100, blocked with $1 \%$ BSA, and then incubated with anti-A $\beta$ (20.1) or anti-HA (2G9) MoAb. Infected cells were then incubated with a secondary anti-mouse FITC-conjugated antibody and visualized under a fluorescence microscope at $\times 20$ magnification. 
A
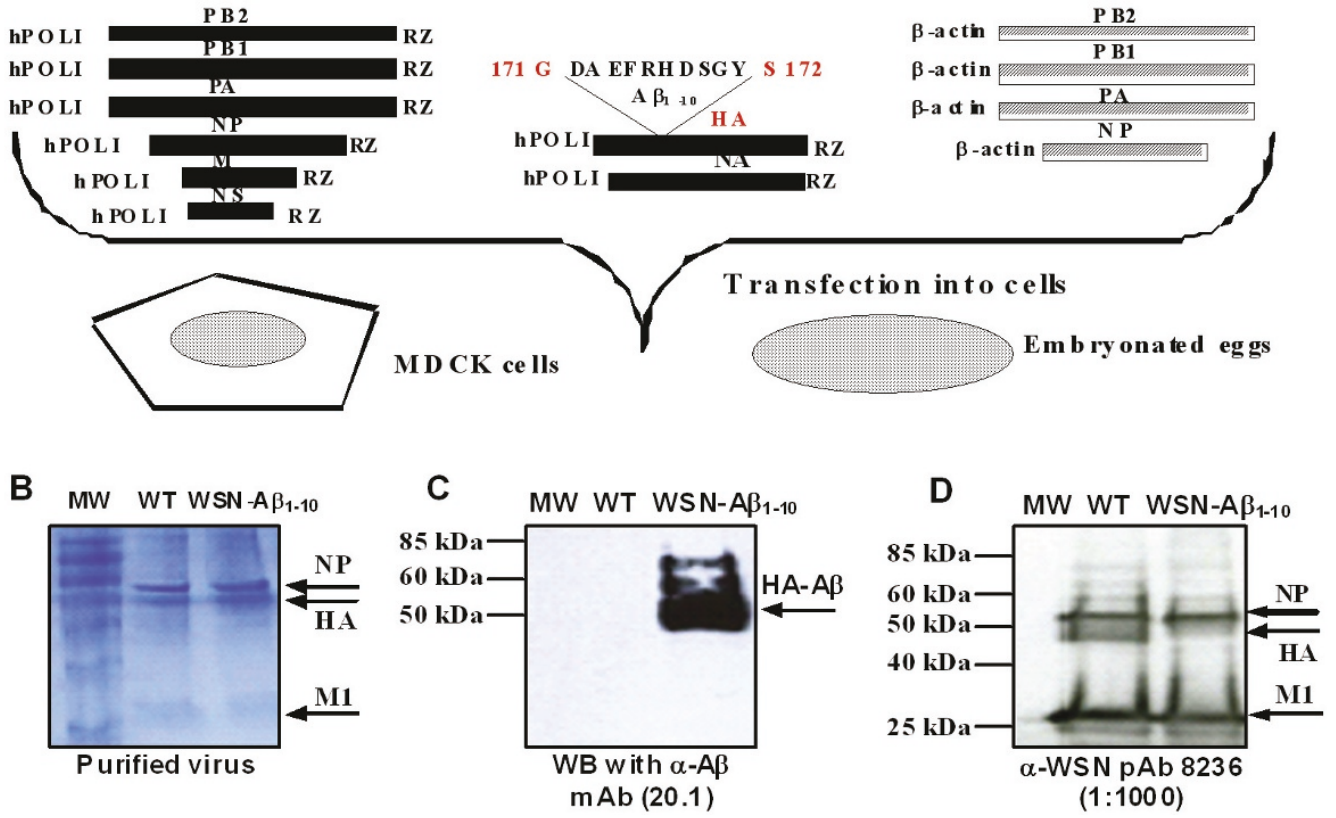

Figure 1 Preparation of chimeric virus: (A) Schematic presentation of the rescue strategy of WSN-A $\beta_{1-10}$ chimeric virus. (B) SDS-PAGE and coomassie staining of purified chimeric (WSN-A $\beta_{1-10}$ ) and wild-type (WT) viruses. (C) WB analysis of purified virus using anti-A $\beta$ antibody revealed the chimeric $H A-A \beta_{1-10}$ protein of the correct size. (D) Proteins corresponding to NP, HA and M1 were detected in WB analysis of purified virus using anti-WSN polyclonal serum.

\section{Hemagglutination inhibition assay}

Hemagglutination inhibition (HI) assays were performed using standard methods [29]. Receptor-destroying enzyme (Vibrio cholera filtrate; Sigma-Aldrich, MO)treated serum as well as the anti-A $\beta$ 20.1, anti-HA (2G9; gift of Drs. Thomas Moran and Peter Palese, Mount Sinai School of Medicine) and irrelevant antiIRF3 antibodies (Invitrogen, CA) were used in these assays. Briefly, two fold dilutions of the indicated monoclonal antibodies or RDE-treated serum from immunized and control mice were prepared in saline solution. The diluted monoclonal antibodies or serum were then incubated with 8 hemagglutination assay (HA) units of wild-type WSN or chimeric virus. After $1 \mathrm{~h}$ incubation at room temperature, chicken red blood cells (RBC) were added to each well (final concentration of $0.5 \%$ ) and incubated for 40 minutes on ice. The HI titer is expressed as the reciprocal of the highest dilution of serum able to inhibit hemagglutination.

Preparation of viral stocks and immunization of mice Viruses were grown in MDCK cells using DMEM containing $0.3 \% \mathrm{BSA}, 1 \mu \mathrm{g}$ Trypsin-TPCK/mL, penicillin, and streptomycin. After $48 \mathrm{~h}$ post-infection, the supernatants were collected and the viruses were pelleted by centrifugation at $25 \mathrm{~K} \mathrm{rpm}$ for $2 \mathrm{~h}$ on a $30 \%$ sucrose cushion (NTE buffer; $100 \mathrm{mM} \mathrm{NaCl} ; 10 \mathrm{mM}$ Tris- $\mathrm{HCl}$, $\mathrm{pH}$ 7.4; $1 \mathrm{mM}$ EDTA). The pellets were resuspended in NTE buffer and re-pelleted by centrifugation at $25 \mathrm{~K}$ for $90 \mathrm{~min}$ in NTE buffer. The pellets were resuspended to $1 \mathrm{mg} / \mathrm{ml}$ concentration and inactivated using formaldehyde for 2 days at $4^{\circ} \mathrm{C}$. To confirm complete inactivation of virus, formaldehyde treated viruses were injected into $10 \mathrm{~d}$ old embryonated eggs and viral replication was examined by hemagglutination assay. Mice were immunized with indicated amount of inactivated viruses formulated in Quil A adjuvant administrated subcutaneously (s.c.) at biweekly intervals. Sera were collected 12 days after each immunization.

\section{Detection of anti-A $\beta$ and anti-HA antibody responses using ELISA}

Concentration of anti-A $\beta$ antibody in sera of immunized and control mice was measured as described previously [21]. Briefly, wells of 96-well plates (Immulon II; Dynax Laboratories, VA) were coated with $2.5 \mu \mathrm{M}$ soluble $\mathrm{A} \beta_{42}$ $\left(\mathrm{pH} 9.7, \mathrm{o} / \mathrm{n}\right.$, and $4^{\circ} \mathrm{C}$ ) or $10 \mu \mathrm{g} / \mathrm{ml}$ protein from inactivated WSN-WT virus. Wells were then washed and blocked, and sera from experimental mice were added to the wells at different dilutions. After incubation and washing, HRP-conjugated anti-mouse IgG (Jackson ImmunoResearch Laboratories, ME) was used as 
secondary antibody. Plates were incubated and washed, and the reaction was developed by adding 3,3,5,5'tetramethylbenzidine (TMB) (Pierce, IL) substrate solution and stopped with $2 \mathrm{M} \mathrm{H}_{2} \mathrm{SO}_{4}$. The optical density (OD) was read at $450 \mathrm{~nm}$ (Biotek, Synergy HT, VT), and anti$\mathrm{A} \beta$ antibody concentrations were calculated using a calibration curve generated with 6E10 monoclonal antibody (Signet, MA). In order to determine half-max binding values of anti-viral antibodies we plotted the $\mathrm{OD}_{450}$ values against the serum dilution as described [30,31]. From this plot we determined half-maximal antibody titers (HMAT) by dividing the highest $\mathrm{OD}_{450}$ value in the dilution range of each serum sample by two. Initial dilution of sera in these experiments was 1:500 and they were serially diluted up to 1:500000. All anti-A $\beta$ concentrations and HMAT were determined in individual mice.

\section{Detection of $A \beta$ plaques in human brain tissues}

Sera from immunized mice were screened for the ability to bind to human $\mathrm{A} \beta$ plaques using $50 \mu \mathrm{m}$ brain sections of formalin-fixed cortical tissue from a severe AD case (received from Brain Bank and Tissue Repository, MIND, UC Irvine) using immunohistochemistry as described previously [20]. A digital camera (Olympus, Tokyo, Japan) was used to capture images of the plaques at an $\times 4$ magnification. The binding of anti-A $\beta$ sera to the $\beta$-amyloid plaques was blocked by $2.5 \mathrm{mM}$ of $\mathrm{A} \beta_{42}$ peptide as described [20].

\section{Neurotoxicity Assay}

Cell culture MTT assay was performed as described previously with minor modifications [24,32]. Human neuroblastoma SH-SY5Y cells (ATCC, VA) were used and aliquoted into 96-well plates (Immulon II; Dynax Laboratories, VA) at approximately $2 \times 10^{4}$ cells per well in $100 \mathrm{ml}$ of medium (45\% DMEM, 45\% Ham's modification of F-12, 10\% FBS and $2 \mathrm{mM}$ L-glutamine) and incubated for $24 \mathrm{~h}$ in $5 \% \mathrm{CO}_{2}$ atmosphere at $37^{\circ} \mathrm{C}$ to allow attachment to the bottom of the wells. $\mathrm{A} \beta$ oligomers and fibrils were prepared as we described previously [24]. $A \beta_{42}$ oligomers and fibrils were incubated alone or with immune sera from WSN-A $\beta_{1-10}$ (experiment) or WSN-WT (control) immunized mice for $1 \mathrm{~h}$ at room temperature with occasional mixing to ensure maximal interaction. After incubation, the peptide/ immune sera mixtures were diluted into culture media so that the final concentration of peptide and antibodies was $2 \mu \mathrm{M}$ and $0.2 \mu \mathrm{M}$, respectively. This media was then added $(100 \mu \mathrm{l})$ to SH-SY5Y cells. The treatment time was $18 \mathrm{~h}$. Untreated controls were run in parallel. Following incubation, neurotoxicity was assayed using the MTT assay according to the manufacturer's instructions (Promega Corp., WI). The absorbance at $570 \mathrm{~nm}$ was measured by Synergy HT Microplate reader (Biotek,
VT). Cell viability was calculated by dividing the absorbance of wells containing samples by the absorbance of wells containing medium alone.

\section{Statistical Analysis}

Statistical parameters (mean, standard deviation (SD), significant difference, etc.) were calculated using Prism 3.03 software (GraphPad Software, Inc., CA). Statistically significant differences were examined using a t-test or analysis of variance (ANOVA) and Tukey's multiple comparisons post-test (a P value of less than 0.05 was considered significant).

\section{Results}

Generation and characterization of chimeric viruses expressing $A \beta_{1-10}$ or $A \beta_{1-7}$ peptides

Previous approaches to develop AD active vaccines based on full-length $\beta$-amyloid have resulted in pathological autoimmunity $[8,9,14-16]$. To improve the safety profile of $\mathrm{AD}$ vaccines, we have constructed chimeric influenza virus $A / W S N / 33(\mathrm{H} 1 \mathrm{~N} 1)$ expressing $B$ cell epitopes of $A \beta_{42}, A \beta_{1-10}\left(W S N-A \beta_{1-10}\right)$ and $A \beta_{1-7}$ (WSN$\left.A \beta_{1-7}\right)$ using plasmid-based reverse genetic techniques described above. Influenza virus contains 200-300 molecules of HA per virion, with each of them possessing 5 antigenic sites that induce majority of neutralizing antibody responses [33]. On the other hand, the immunodominant $B$ cell epitope of $A \beta_{42}$ has been mapped to the $\mathrm{N}$ terminus of this peptide [30,34-40] and, importantly, these peptides do not possess $\mathrm{T}$ helper epitope/s [35,41]. Accordingly, $A \beta_{1-10}$ (Figure 1A) and $A \beta_{1-7}$ (data not shown) epitopes of $A \beta_{42}$, were inserted into one of five HA antigenic sites between amino acids 171 and 172 . The other four antigenic sites of HA remained unaltered so they could induce virus-neutralizing antibodies. Generated chimeric viruses were purified and the expression of inserted antigens was tested. As shown in Figure 1B, coomassie staining of SDS-PAGE resolved purified viruses revealed that the purity of both chimeric (WSN$\mathrm{A} \beta_{1-10}$ ) and wild-type (WSN-WT) viruses reached to > $90 \%$. Immunoblot analysis conducted with anti-A $\beta$ monoclonal antibody (20.1) demonstrated that chimeric, but not WT, virus expressed an $\mathrm{A} \beta$ peptide incorporated into the viral protein (HA) (Figure 1C), while both viruses expressed HA, NP and M1 proteins detected with anti-WSN antibodies (Figure 1D). Of note, to make it simple, only data with WSN-A $\beta_{1-10}$, but not WSN$\mathrm{A} \beta_{1-7}$ were presented in Figure 1.

Next, we compared the ability of WT virus and A $\beta$ peptide expressing chimeric viruses to infect the host cells in vitro by immunofluorescence assay. MDCK cells mock-infected or infected with WSN-WT, WSN-A $\beta_{1-10}$ or WSN-A $\beta_{1-7}$ were stained with either anti-A $\beta$ (20.1) or anti-HA (2G9) monoclonal antibodies (Figure 2.). 


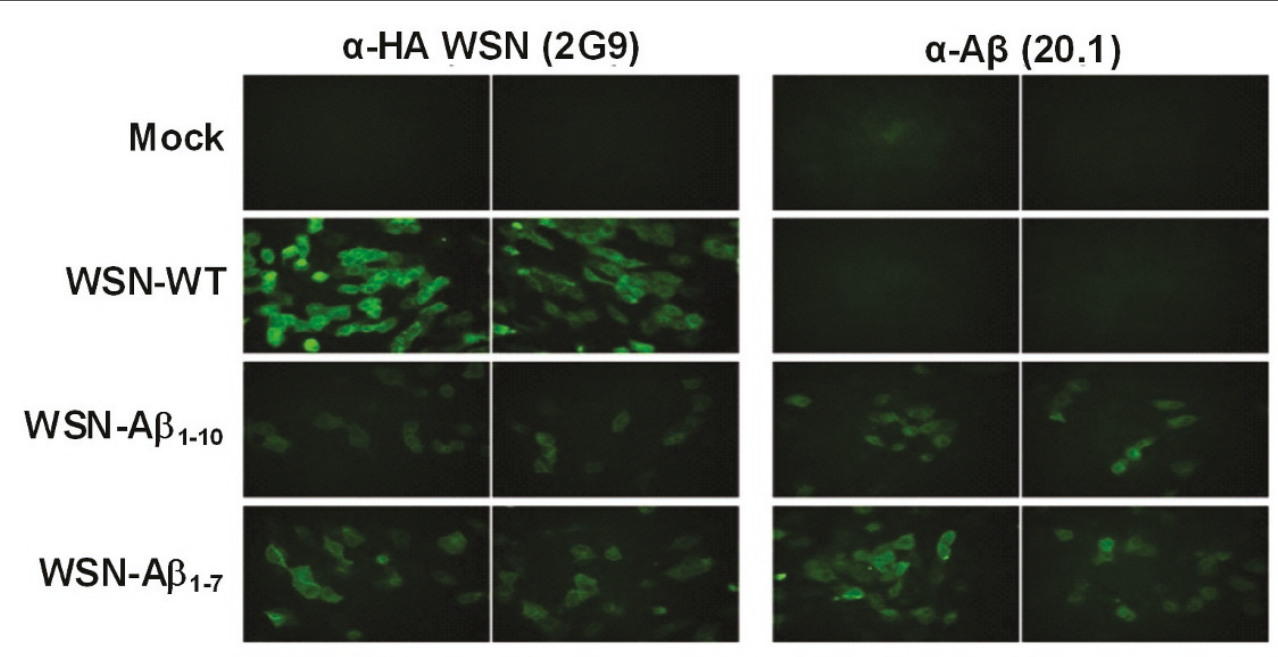

Figure 2 Expression of $\beta$-amyloid $B$ cell epitopes by chimeric influenza virus WSN (WSN-A $\beta_{1-10}$ and WSN-A $\left.\beta_{1-7}\right)$. MDCK cells infected

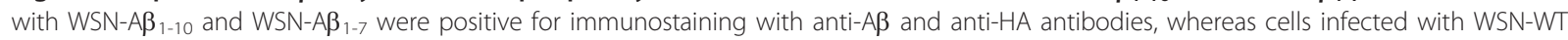
were positive only with anti-HA antibody.

Importantly, WSN-WT-infected cells stained positive only with anti-HA antibody. WSN-A $\beta_{1-10}$ or WSN-A $\beta_{1-}$ 7 infected cells stained positive for $A \beta$ and anti-HA (Figure 2). These data supported biochemical results presented in Figure 1 and also suggested that the insertion of $A \beta$ peptide into the HA molecule did not perturb the infectivity of the chimeric flu virus. A hemagglutination inhibition (HI) assay (Figure 3) was next conducted to analyze the impact of the $A \beta$ insertion in recognition of the HA by neutralizing antibodies. Interestingly, anti-A $\beta$ monoclonal antibody (20.1) inhibited hemagglutination of chicken red blood cells (RBC) by WSN-A $\beta_{1-10}$ or WSN-A $\beta_{1-7}$ viruses, but not by WSN-WT (Figure 3 ). The anti-HA monoclonal antibody (2G9) inhibited hemagglutination of RBC by chimeric and wildtype viruses, whereas a negative control antibody specific for

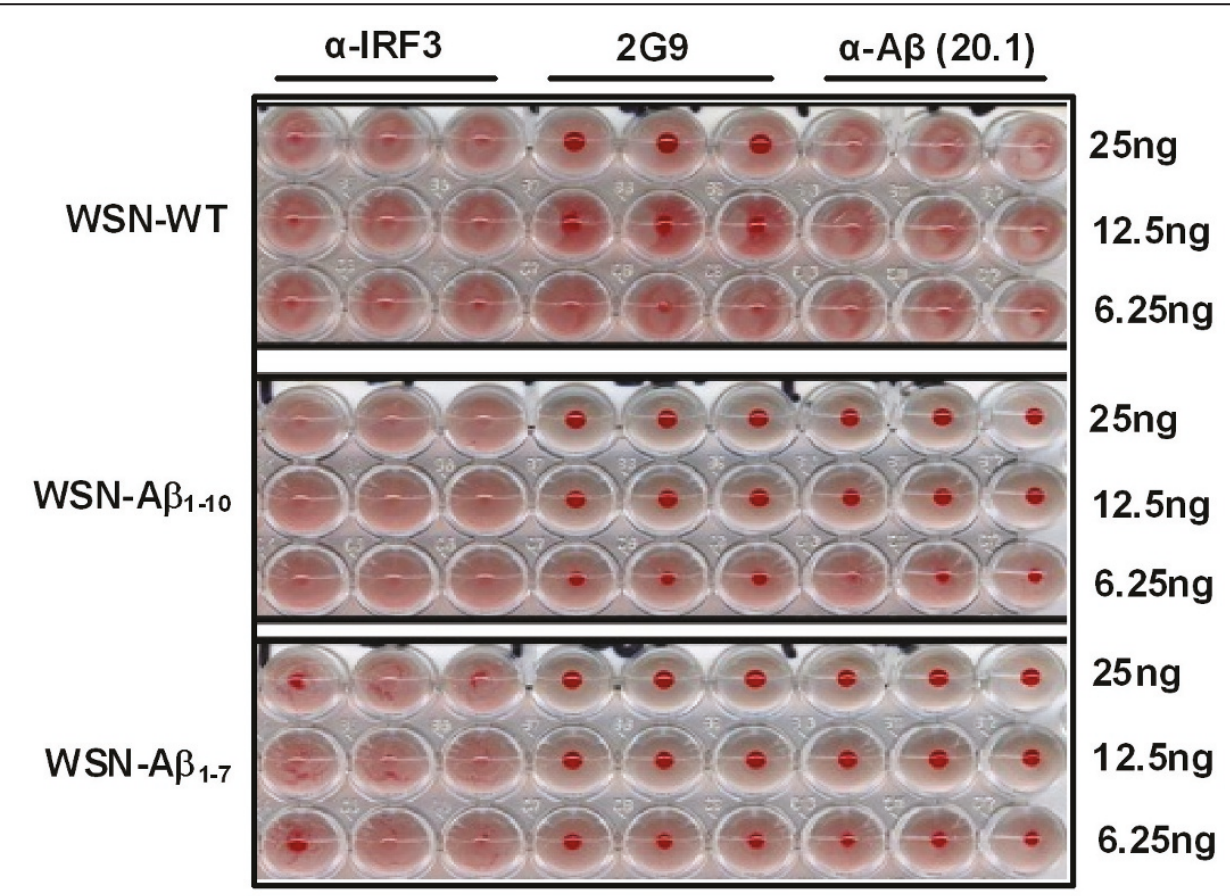

Figure 3 Anti-HA antibodies inhibited agglutination of RBC by both wild-type and chimeric influenza viruses, while anti-A $\beta$ antibodies only inhibited agglutination of RBC by the chimeric virus. 
IRF3 did not inhibit hemagglutination. These data demonstrate that (i) the $A \beta$ epitope is displayed on the virus surface allowing for the recognition by anti-A $\beta$ antibodies and (ii) the insertion of $\mathrm{A} \beta$ peptide did not drastically change the conformation of the HA molecule and did not disturb its functional ability.

\section{WSN-A $\beta_{1-10}$ is more immunogenic than WSN-A $\beta_{1-7}$}

To evaluate the ability of chimeric influenza viruses expressing $A \beta_{1-10}$ and $A \beta_{1-7}$ peptides to induce anti-A $\beta$ antibody responses, $\mathrm{C} 57 \mathrm{Bl} / 6$ mice were immunized with $20 \mu \mathrm{g} /$ mouse purified inactivated chimeric viruses (formulated in a strong Th1 type adjuvant, QuilA, three times with two weeks interval (Table 1, Study 1).

Control groups of mice were immunized with $20 \mu \mathrm{g} /$ mouse of inactivated purified WSN-WT. An A $\beta$-specific ELISA revealed that both chimeric influenza viruses expressing $A \beta_{1-10}$ or $A \beta_{1-7}$ induced anti-A $\beta$ antibody responses after three immunizations; however, antibody responses were significantly stronger for $\mathrm{WSN}-\mathrm{A} \beta_{1-10}$ immunized mice as compared to $\mathrm{WSN}-\mathrm{A} \beta_{1-7} \mathrm{immu}-$ nized mice (Figure 4). No anti- $\mathrm{A} \beta$ response was seen in the control group of mice immunized with WSN-WT (Figure 4). Based on the higher ELISA titer, the chimeric influenza virus WSN-A $\beta_{1-10}$ was chosen for further experiments.

\section{Humoral immune responses generated by WSN-WT and WSN-A $\beta_{1-10}$ vaccines are dose-dependent}

Next we investigated the effects of an increased antigen dose on generation of anti- $\mathrm{A} \beta$ and anti-influenza antibodies (Table 1, Study 2). C57Bl/6 mice were immunized with three different doses $(5 \mu \mathrm{g}, 25 \mu \mathrm{g}$ and $50 \mu \mathrm{g}$ per mouse) of WSN-A $\beta_{1-10}$ or WSN-WT.

Table 1 Design of immunization studies in wild-type mice

\begin{tabular}{|c|c|c|c|c|}
\hline Study & Group & Immunogen & $\begin{array}{c}\text { Dosage } \\
(\mu \mathrm{g} / \\
\text { mouse })\end{array}$ & $\begin{array}{l}\text { Total number of } \\
\text { Immunizations }\end{array}$ \\
\hline \multirow{3}{*}{$\begin{array}{c}\text { Study } \\
1\end{array}$} & 1 & WSN-WT & 20 & 3 \\
\hline & 2 & $W S N-A \beta_{1-7}$ & 20 & 3 \\
\hline & 3 & $W S N-A \beta_{1-10}$ & 20 & 3 \\
\hline \multirow{6}{*}{$\begin{array}{c}\text { Study } \\
2\end{array}$} & 1 & WSN-WT & 5 & 3 \\
\hline & 2 & WSN-WT & 25 & 3 \\
\hline & 3 & WSN-WT & 50 & 3 \\
\hline & 4 & $W S N-A \beta_{1-10}$ & 5 & 3 \\
\hline & 5 & $W S N-A \beta_{1-10}$ & 25 & 3 \\
\hline & 6 & $W S N-A \beta_{1-10}$ & 50 & 3 \\
\hline \multirow{2}{*}{$\begin{array}{c}\text { Study } \\
3\end{array}$} & 1 & WSN-WT & 50 & 6 \\
\hline & 2 & $W S N-A \beta_{1-10}$ & 50 & 6 \\
\hline
\end{tabular}

Humoral immune responses were evaluated in all groups after the third immunization (Figure 5). Immunizations with $5 \mu \mathrm{g} /$ mouse or $25 \mu \mathrm{g} /$ mouse doses of WSN-A $\beta_{1-10}$ induced relatively low levels of anti-A $\beta$ antibodies $(7.47 \pm 5.29 \mu \mathrm{g} / \mathrm{ml}$ and $9.47 \pm 3.52 \mu \mathrm{g} / \mathrm{ml}$, respectively). However, $50 \mu \mathrm{g} /$ mouse dose of WSN$\mathrm{A} \beta_{1-10}(40.01 \pm 35.66 \mu \mathrm{g} / \mathrm{ml})$ induced strong anti- $\mathrm{A} \beta$ antibody response that was significantly higher $(\mathrm{P} \leq$ $0.05)$ than that in mice vaccinated with $5 \mu \mathrm{g} /$ mouse or $25 \mu \mathrm{g} /$ mouse doses (Figure 5A). Both $25 \mu \mathrm{g} /$ mouse and $50 \mu \mathrm{g} /$ mouse doses of WSN-A $\beta_{1-10}$ induced significantly higher $(\mathrm{P} \leq 0.05)$ titers of anti-WSN antibody $(\sim 75,000$ and $\sim 80,000$, respectively) than that in mice immunized with $5 \mu \mathrm{g} /$ mouse dose of WSN-A $\beta_{1-10}$ $(\sim 45,000)$ (Figure $5 \mathrm{~B})$. Of note, although the anti-WSN antibody response was slightly higher in mice immunized with $50 \mu \mathrm{g}$ WSN-A $\beta_{1-10}$ compared with that in mice immunized with $25 \mu \mathrm{g}$ WSN-A $\beta_{1-10}$, this difference was not significant. In case of immunization with WSN-WT virus the dose-dependent nature of humoral response was more evident. $50 \mu \mathrm{g} /$ mouse of WSN-WT induced significantly higher titers of anti-influenza antibodies $(\sim 125,000)$ than $25 \mu \mathrm{g} /$ mouse $(\sim 110,000, \mathrm{P}$ $\leq 0.05)$ and $5 \mu \mathrm{g} /$ mouse doses $(\sim 25,000, \mathrm{P} \leq 0.001)$, respectively (Figure $5 \mathrm{C}$ ). Thus, mice immunized with $50 \mu \mathrm{g}$ of inactivated chimeric virus generated the strongest anti-amyloid and anti-influenza humoral immune responses and this dose of vaccine have been used in our further experiments described below.

\section{Kinetics of antibody responses in mice immunized with WSN-WT and WSN-A $\beta_{1-10}$ viruses}

The kinetics of anti-A $\beta$ antibody and anti-influenza antibody responses in mice vaccinated with WSN-A $\beta_{1-10}$ or WSN-WT were analyzed to determine the minimal number of vaccinations required to achieve maximal humoral responses and to determine if a correlation existed between the kinetics of $\mathrm{A} \beta$ antibody and influenza virus HA responses. Two groups of mice were immunized six times biweekly with inactivated WSN$A \beta_{1-10}$ or WSN-WT formulated in Quil A adjuvant (Table 1, Study 3). The concentration of anti-A $\beta$ antibodies was measured in sera of mice after each immunization starting from the second immunization (Figure 6A). The highest $A \beta$ antibody titer was detected after the $3^{\text {rd }}$ immunization with WSN-A $\beta_{1-10}(56.47 \pm 30.18 \mu \mathrm{g} / \mathrm{ml})$. Further immunizations did not change the level of anti$A \beta$ antibodies as the titers reached a plateau (after $6^{\text {th }}$ immunization titers were still the same $=46.43 \pm 42.66$ $\mu \mathrm{g} / \mathrm{ml})$. As expected, WSN-WT immunized mice did not show any detectable anti-A $\beta$ antibody responses (data not shown).

Importantly, immunization with WSN-A $\beta_{1-10}$ elicited also high titers of anti-WSN antibodies after the second 


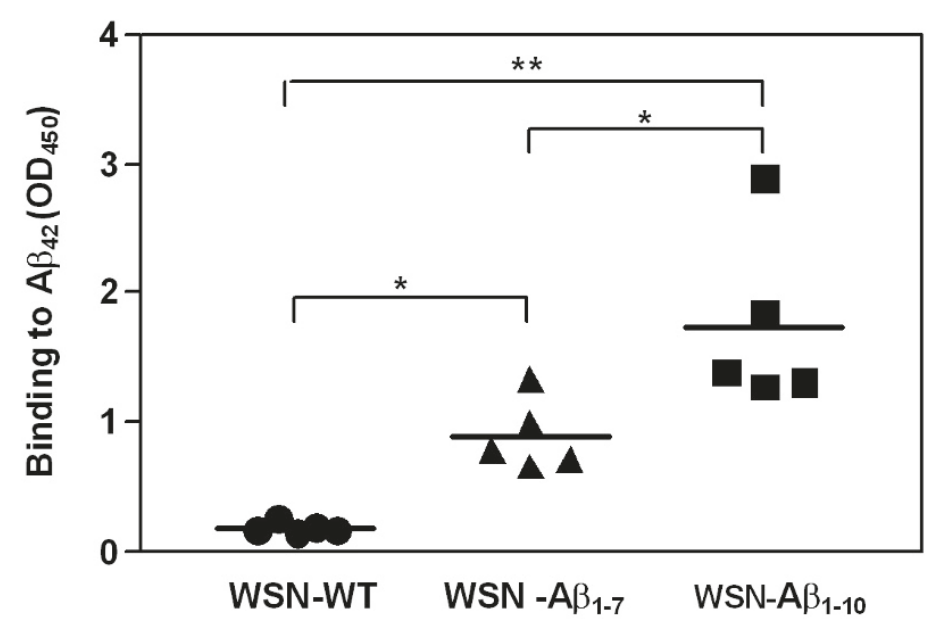

Figure 4 Mice immunized with killed WSN-A $\beta_{1-10}$ virus generated significantly higher anti-A $\beta_{42}$ specific antibodies compared with that in mice immunized with WSN-A $\boldsymbol{\beta}_{1-7}$. Anti-A $\beta$ antibody responses were measured in sera of individual mice immunized 3 times with indicated viruses at dilution 1:200. Lines represent the average $\left(n=5,{ }^{*} P<0.05 ;{ }^{* *} P<0.01\right)$.

immunization, and these titers became even higher after each subsequent immunization reaching up to $\sim 125,000$ after six immunizations (Figure 6B). In contrast, WSNWT immunization elicited the highest level of anti-influenza antibody much quicker (after $4^{\text {th }}$ immunization titer of antibodies was $\sim 125,000$ ), which then decreased after $5^{\text {th }}$ and $6^{\text {th }}$ immunizations (Figure 6B). Thus, although after early immunizations the titers of antiinfluenza antibodies were significantly higher in mice immunized with WSN-WT than with WSN-A $\beta_{1-10}$, the pattern was changed after further immunizations. Interestingly, after the 6th immunizations titers of anti-
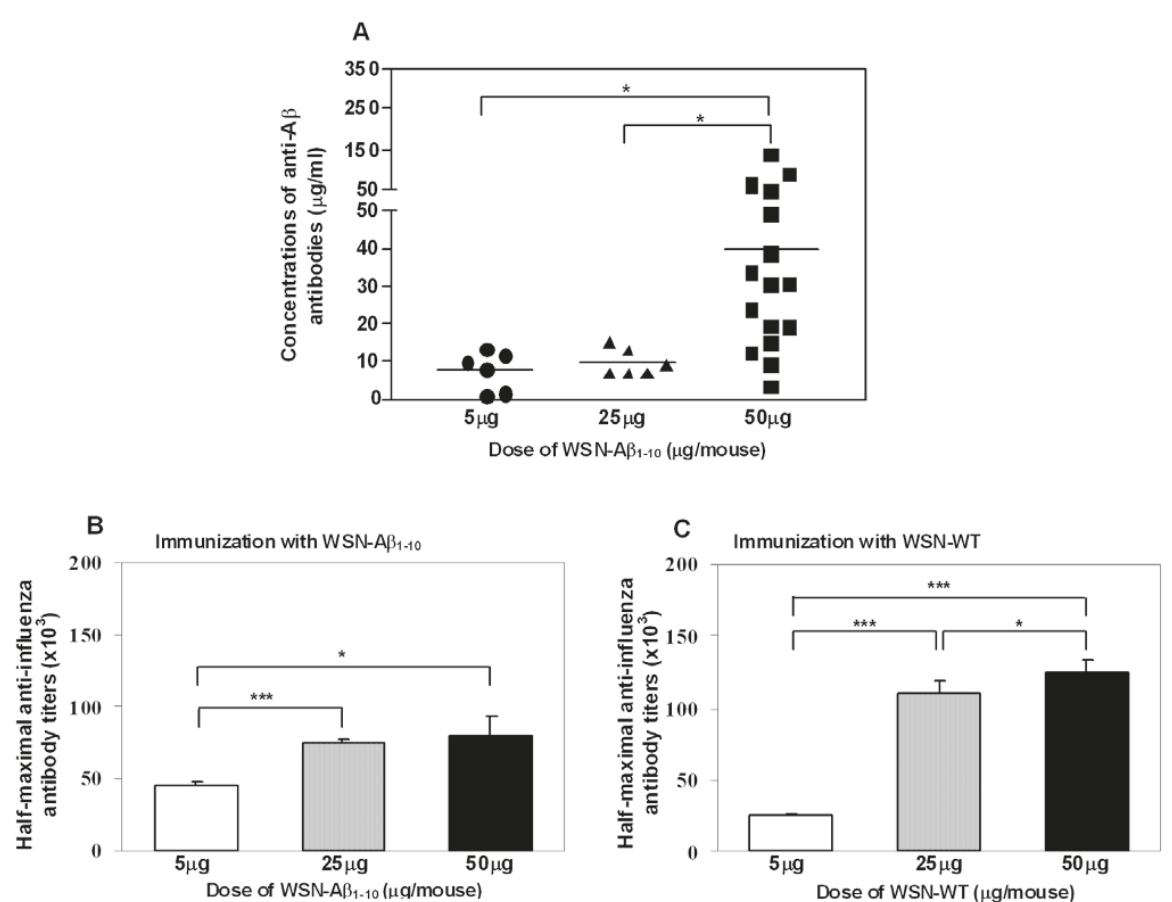

Figure 5 Anti-A $\beta$ and anti-WSN immune responses in mice immunized with different doses of WSN-A $\beta_{1-10}$ and WSN-WT: Anti-A $(A)$ and anti-WSN $(B, C)$ antibodies were analyzed in sera of individual mice immunized 3 times with indicated doses of killed WSN-A $\beta_{1-10}$ and WSNWT viruses formulated in Quil A. Lines and error bars indicate the average \pm s.d. ( $n=6$ for groups immunized with 5 and $25 \mu \mathrm{g}$ and $\mathrm{n}=16$ for groups immunized with $50 \mu \mathrm{g}$ killed viruses $\left({ }^{*} P<0.05 ;{ }^{* *} P<0.001\right)$. 


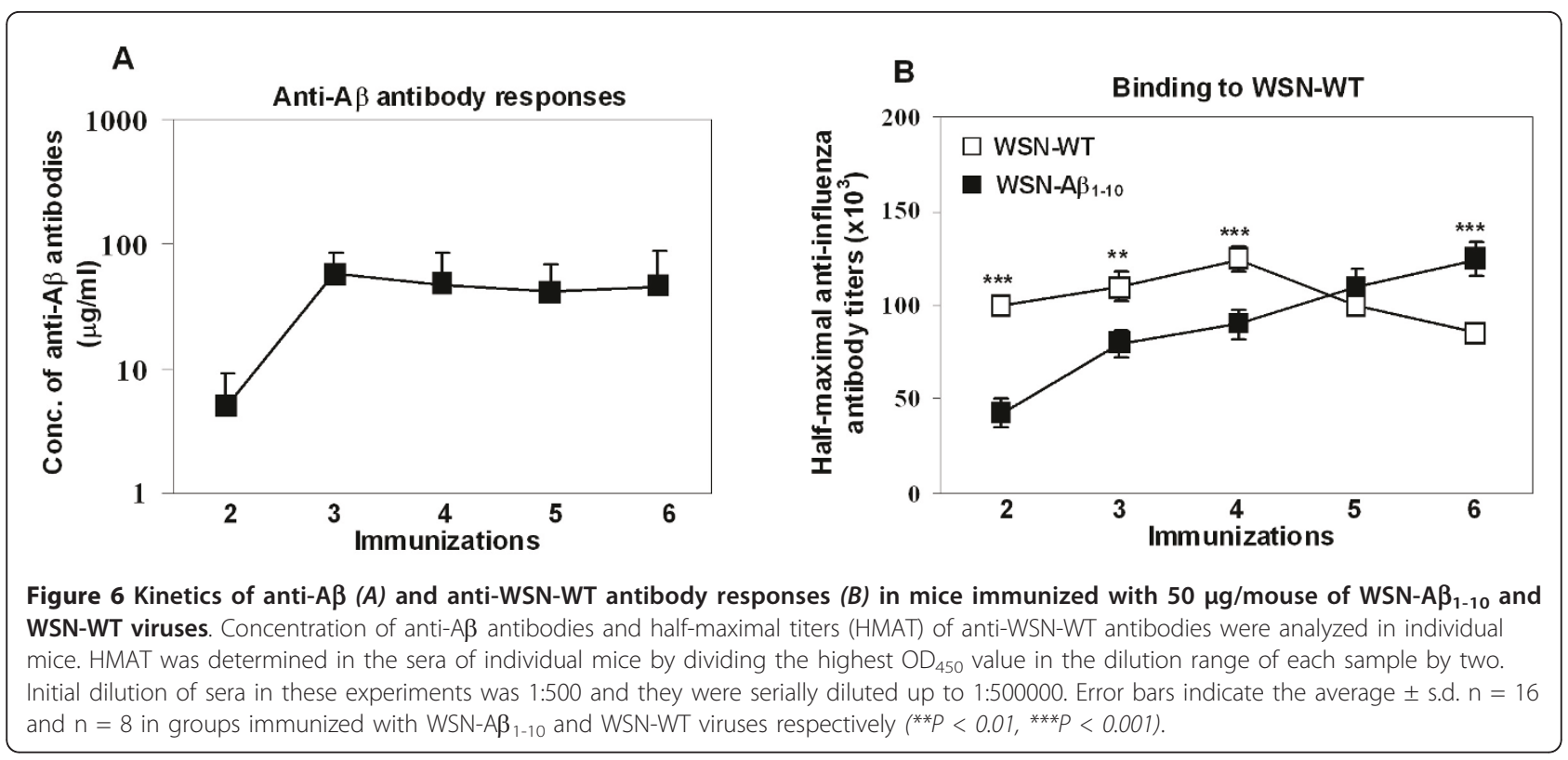

influenza antibody elicited by WSN-A $\beta_{1-10}$ were significantly higher than that elicited by WSN-WT.

\section{Anti-A $\beta$ and anti-influenza antibodies are therapeutically potent}

To show the therapeutic potential of dual chimeric vaccine we first analyzed binding of antisera to $A \beta$ plaques in brain tissue from an $\mathrm{AD}$ case. As we expected from our previous studies [20,22,24], sera generated after immunizations of mice with WSN-A $\beta_{1-10}$ bound to $\beta$-amyloid plaques very well (Figure $7 \mathrm{~A}$ ). This binding was specific to $A \beta$ since it was blocked by preabsorption of antisera with $A \beta_{42}$ peptide (Figure $7 \mathrm{~B}$ ). As one could expect from data presented above, sera obtained from mice immunized with WSN-WT did not bind to $\mathrm{A} \beta$ deposits in $\mathrm{AD}$ brain tissue at all (Figure $7 \mathrm{C})$.
The important feature of functional anti- $\mathrm{A} \beta$ antibody is the binding to all species of $A \beta_{42}$ peptide and inhibition of cytotoxic effect of $A \beta_{42}$ oligomers and fibrils on human neuroblastoma SH-SY5Y cells. We demonstrated that immune sera from mice immunized with WSN-A $\beta_{1-10}$ bound very well to monomeric, oligomeric and fibrillar forms of $A \beta_{42}$ peptide in a dot blot assay (Figure $8 \mathrm{~A}$ ). Thus, we confirmed that $\mathrm{WSN}-\mathrm{A} \beta_{1-}$ 10 vaccine induced anti-A $\beta$ antibodies capable of binding not only to $A \beta_{42}$ oligomers and fibrils in vitro, but also to plaques of AD case. These data suggested that anti-A $\beta$ antibody generated by WSN-A $\beta_{1-10}$ vaccine is therapeutically potent and might exhibit a protective effect on $A \beta$-induced neurotoxicity. To test that, we performed in vitro assessment using human neuroblastoma SH-SY5Y cells. The data showed that both $\mathrm{A} \beta_{42}$ fibrils and oligomers are cytotoxic, reducing cell
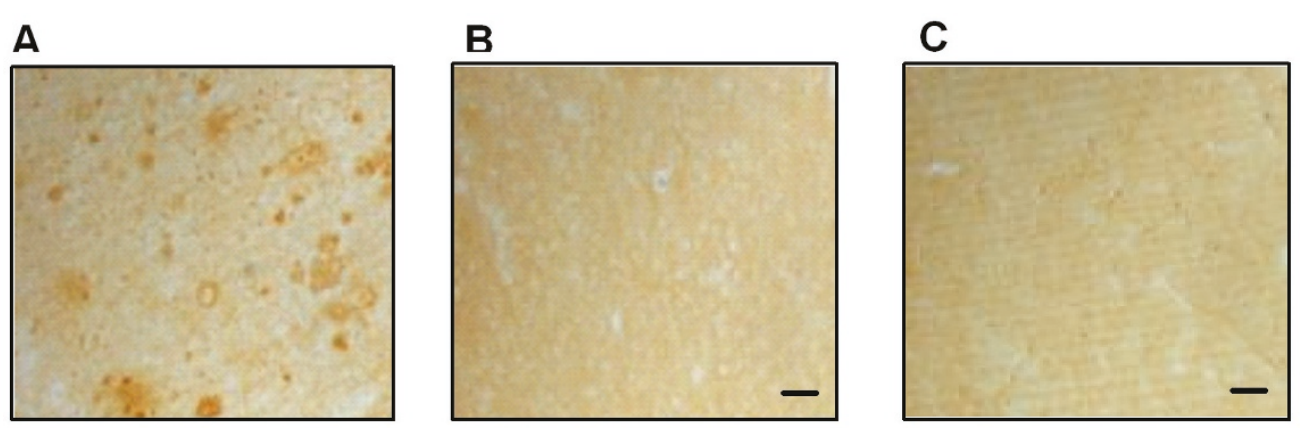

Figure $\mathbf{7}$ Therapeutic potency of anti-A $\boldsymbol{\beta}$ antibody generated in mice immunized with $\mathbf{W S N}-\mathbf{A} \boldsymbol{\beta}_{1-10}$ : (A) Immune sera generated after immunization with killed WSN-A $\beta_{1-10}$ (at dilution 1:600) bound to the brain sections of cortical tissues from an AD case and (B) this binding was blocked by pre-absorption of sera with $A \beta_{42}$ peptide. (C) Immune sera generated after immunization with killed WSN-WT (at dilution 1:600) did not bind to the brain sections of cortical tissues from an AD case. Original magnification was $\times 4$ and scale bar was $200 \mu \mathrm{m}$. 
viability to about $67.7 \%$ and $59.8 \%$, respectively (Figure 8B). Pre-incubation of $A \beta_{42}$ fibrils with immune sera from WSN-A $\beta_{1-10}$ vaccinated mice resulted in the rescue of cell viability to maximum level ( 97.5\%). Similarly, pre-incubation of $A \beta_{42}$ oligomers with anti-A $\beta_{1-}$ 10 antibody increased cell viability to approximately $90.9 \%$. In contrast, pre-incubation of both $A \beta_{42}$ species with immune sera from WSN-WT immunized mice (control) did not rescue cells from oligomer or fibermediated cell death. These data suggest that anti-A $\beta_{1-}$ 10 antibody generated by WSN-A $\beta_{1-10}$ chimeric vaccine inhibits $A \beta_{42}$ fiber-mediated neurotoxicity and alleviates oligomer-mediated toxicity in vitro.
Next in order to understand the dual potency of WSN-A $\beta_{1-10}$ it was important to analyze the anti-viral efficacy of antibodies generated by the chimeric vaccine. The level of neutralizing anti-viral antibodies in immunized mice was measured using the HI assay described above. HI antibody titers were determined in groups immunized with different doses $(5 \mu \mathrm{g}, 25 \mu \mathrm{g}$, or $50 \mu \mathrm{g})$ of chimeric and wildtype viruses against both types of viruses: WSN-A $\beta_{1-10}$ and WSN-WT (Table 1, Study 2). After 3 immunizations all mice had measurable titers (> 1:40) of $\mathrm{HI}$ antibodies against both viruses. The titers of $\mathrm{HI}$ antibody in pre-bleed sera were $<1: 10$ (data not shown). Immunization with $50 \mu \mathrm{g} /$ mouse $\mathrm{WSN}-\mathrm{A} \beta_{1-10}$

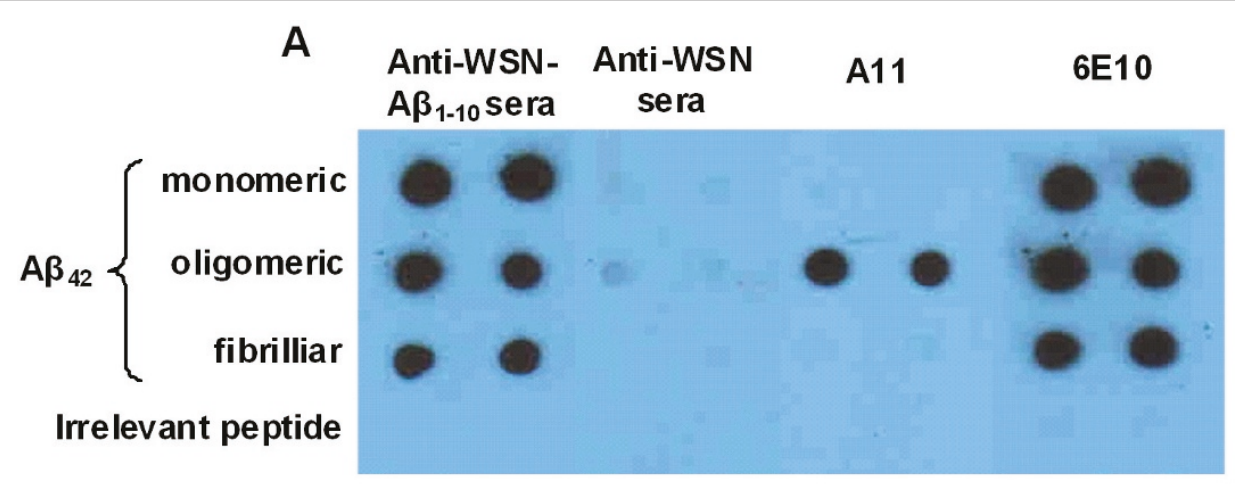

B

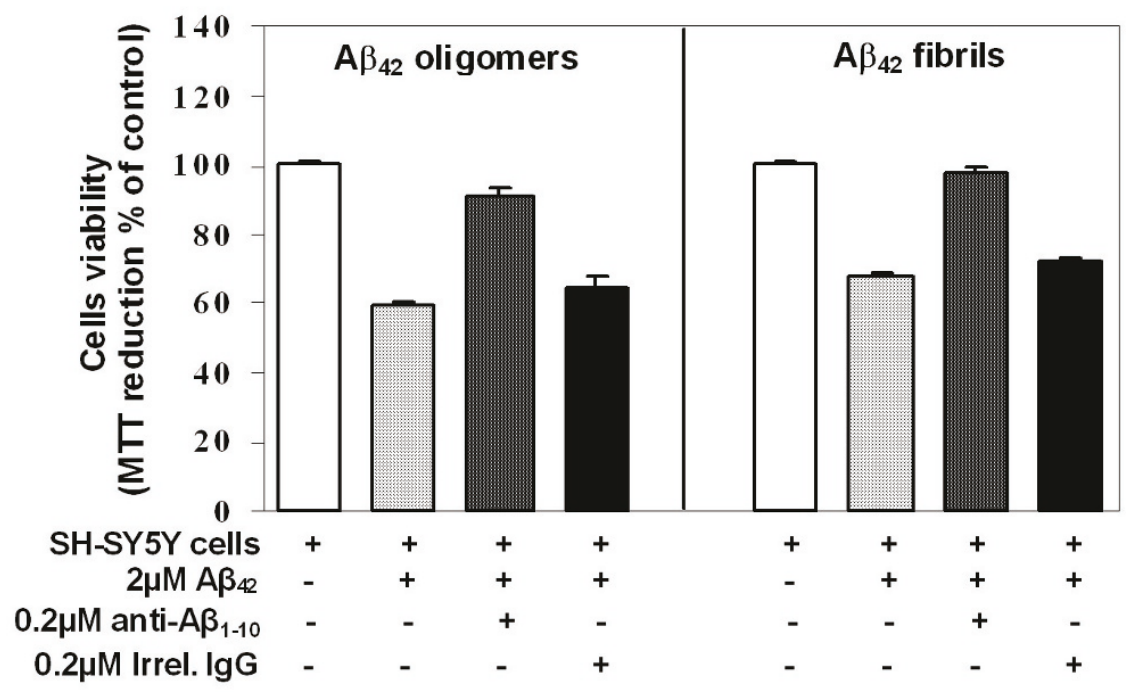

Figure 8 Antibodies generated in mice immunized with dual vaccine, WSN-A $\beta_{1-10}$ bind to $A \beta_{42}$ and inhibit its neurotoxicity: (A) Sera isolated from WSN-A $\beta_{1-10}$, but not WSN-WT vaccinated mice at dilution 1:200 bound to all species of $A \beta_{42}$ peptide, including oligomers recognized by A11 oligomer-specific antibodies. Control monoclonal 6 E10 antibody bound to all forms of $A \beta_{42}$ peptide. (B) Anti-A $\beta_{1-10}$ inhibits $A \beta_{42}$ fibrils- and oligomer-mediated toxicity. Human neuroblastoma SH-SY5Y cells were incubated with $A \beta_{42}$ oligomers and $A \beta_{42}$ fibrils, in the presence or absence of anti-A $\beta_{1-10}$ antibody or irrelevant mouse lgG. Control cells were treated with the vehicle, and cell viability was assayed in all cultures using the 3-(4,5-dimethylthiazol-2-yl)-2,5-diphenyltetrazolium bromide assay. Data were collected in four replicate and was expressed as a percentage of control \pm s.d. 
induced significantly higher titers of $\mathrm{HI}$ antibodies against both wild-type and chimeric viruses than the immunizations by $5 \mu \mathrm{g} /$ mouse and $25 \mu \mathrm{g} /$ mouse doses of WSN-A $\beta_{1-10}(\mathrm{P} \leq 0.05$ and $\mathrm{P} \leq 0.01$, respectively, Figure $9 \mathrm{~A}, \mathrm{~B})$. No significant differences in titers of HI antibodies against both chimeric and wild type WSN viruses were observed in mice immunized with three different doses of WSN-WT (Figure 9A and 9B). The kinetics of anti-HA neutralizing antibodies were also analyzed in the sera of mice immunized with $50 \mu \mathrm{g} /$ mouse dosage of WSN-A $\beta_{1-10}$ and WSN-WT (Table 1, Study 3). The titers of HI antibodies were measured after two, three and four immunizations against WSNWT (Figure 10A) and WSN-A $\beta_{1-10}$ (Figure 10B) viruses using $\mathrm{HI}$ assay. Both viruses elicited equal titers of functional anti-HA antibodies inhibiting hemagglutination by wild-type virus. However, titers of functional antibodies inhibiting hemagglutination by WSN-A $\beta_{1-10}$ virus was significantly higher in mice immunized with WSN$\mathrm{A} \beta_{1-10}$ than in mice immunized with WSN-WT $(\mathrm{P} \leq$ 0.01 and $\mathrm{P} \leq 0.05$ after $3^{\text {rd }}$ and $4^{\text {th }}$ immunizations, respectively, Figure 10B). Thus, chimeric WSN-A $\beta_{1-10}$ vaccine was at least as good as WSN-WT in generation of virus neutralizing antibodies, however it had an additional benefit as it also induced therapeutically potent anti-AD antibodies.

\section{Discussion}

Different approaches that aimed to prevent $A \beta$ overproduction or accelerate its degradation are currently being developed for treatment of AD. However all available treatments have only relatively small symptomatic benefits and could not delay or halt the progression of the disease. As a result, there is no cure from AD today.
A potentially powerful strategy is immunotherapy with anti- $\mathrm{A} \beta$ antibody that can facilitate the reduction of pathological forms of $A \beta$ in the brain [42-52] via several pathways, including catalytic dissolution of amyloid deposits by antibodies; Fc mediated macrophage phagocytosis of amyloid; non-Fc mediate macrophage amyloid clearance; a peripheral sink, whereby $A \beta$ is drawn out of the brain into the peripheral circulation $[53,54]$.

The results of the first $\mathrm{AD}$ clinical trial using the AN1792 vaccine confirmed that anti-A $\beta$ antibodies are beneficial for $\mathrm{AD}$ patients and may at least slow the progression of a disease. However this trial raised concerns about the safety and the efficacy of the active immunization strategy with $A \beta_{42}$ self-peptide. Although the results from the Phase I trial showed good tolerability, in the phase IIa portion of the AN-1792 immunotherapy a subset of individuals developed adverse events in the central nervous system [8-11,14-17]. Further examinations demonstrated that these adverse effects were presumably due to the infiltration of autoreactive $\mathrm{T}$ cells, rather than anti- $\mathrm{A} \beta$ antibody. In addition, the relatively low antibody titers generated even after multiple immunizations and non-responsiveness in $\sim 80 \%$ of patients indicating that the $A \beta$ self-antigen vaccine was not a strong immunogen, suggest that alternative immunotherapeutic strategies should be pursued.

Based on data that the immunodominant $B$ cell epitope of $A \beta_{42}$ has been mapped to the $\mathrm{N}$-terminus of this peptide (aa spanning residues 1-5, 1-7, 1-8, 1-11, 1$15,1-16$, or $4-10)[34,35,37,39,55]$ and that this $A \beta_{1-11}$ peptide does not contain a $\mathrm{T}$ cell epitope in mice [35] or in humans [56], we proposed to use a prototype epitope vaccine that contains the small immunodominant self- $B$ cell epitope of $A \beta$ in tandem with promiscuous
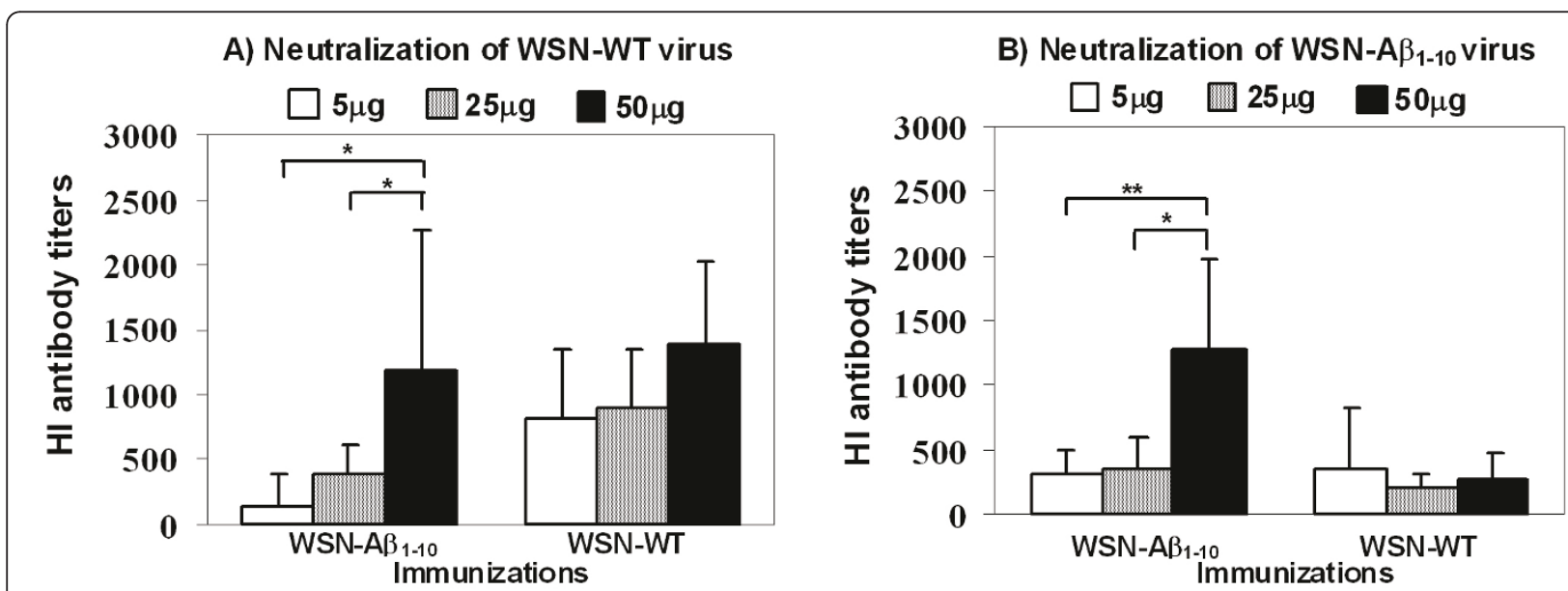

Figure 9 Antibodies generated in mice immunized with dual vaccine, WSN-A $\beta_{1-10}$ neutralize both WSN-WT $(A)$ and WSN-A $\beta_{1-10}(B)$ viruses. Titers of $\mathrm{HI}$ antibody against WSN-WT $(A)$ or WSN-A $\beta_{1-10}(B)$ viruses were measured in individual mice $(n=6 /$ per group) after 3 immunizations. The statistical difference between each group was determined $\left({ }^{*} P<0.05\right.$; $\left.{ }^{* *} P<0.01\right)$. 
A) Neutralization of WSN-WT virus

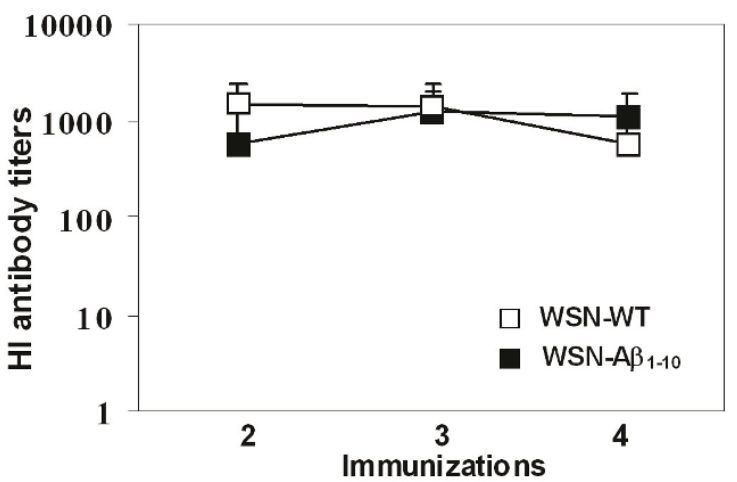

B) Neutralization of WSN-A $\beta_{1-10}$ virus

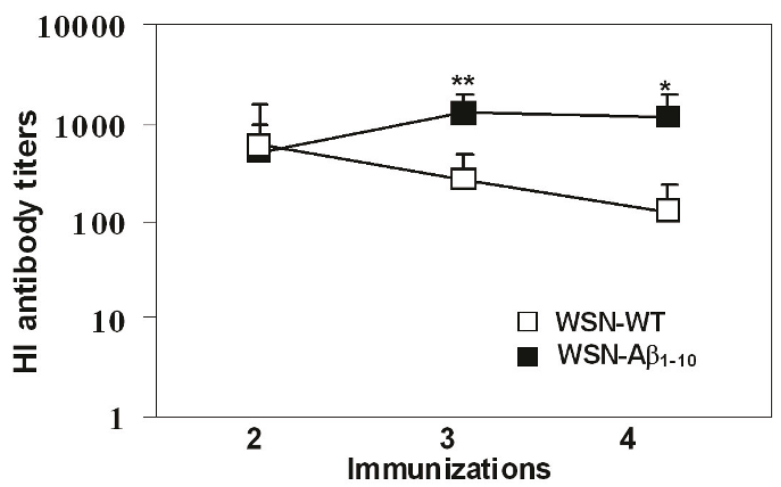

Figure 10 Virus neutralization titers of sera generated after 2, 3 and $4^{\text {th }}$ immunizations with dual vaccine and WSN-WT are the same. $\mathrm{HI}$ titers against WSN-WT (A) and WSN-A $\beta_{1-10}(B)$ were evaluated in sera of individual mice immunized after 2, 3, and 4 immunizations with WSN-WT (close sq) or WSN-A $\beta_{1-10}$ (open sq). Error bars indicate the average \pm s.d. for mice immunized with WSN-A $\beta_{1-10}(n=16)$ or WSN-WT $(n$ $=8)\left({ }^{*} P<0.01 ;{ }^{* *} P<0.01\right)$.

foreign $\mathrm{T}$ helper cell epitope/s, in order to reduce the risk of an adverse $\mathrm{T}$ cell-mediated immune response to A $\beta$-immunotherapy [20]. The efficacy and immunogenicity of our peptide and DNA-based epitope vaccines have been previously tested in the pre-clinical trials [23-25]. Other groups of scientists and different pharmaceutical companies are working on development of epitope-based $A D$ vaccines composed of self-A $\beta$ B cell epitope attached to the carrier protein rather than small foreign Th epitope [57]. Another category of epitope vaccines are those based on viral-like particles (VLP) [58-61]. Incorporation of the A $\beta$ B cell epitope into a viral capsid protein or scaffold proteins allows the expression of this epitope on the surface of VLP in a repetitive and ordered array. Such organization of the epitope may induce $\mathrm{T}$ cell-independent $\mathrm{B}$ cell activation and production of anti-A $\beta$ antibodies of IgM isotype. On the other hand, $T$ cell epitopes from the viral proteins may help $\mathrm{B}$ cells to induce $\mathrm{T}$ cell-dependent humoral responses and produce antibodies of other isotypes. In fact, high titers of persisting long-term anti-A $\beta$ antibodies were induced by recombinant protein based on pyruvate dehydrogenase complex of B. stearothermophilus fused with $A \beta_{1-11} B$ cell epitope. This protein self assembles in vitro into a high molecular mass scaffold with icosahedral symmetry exposing $A \beta B$ cell epitope on a surface [62]. Therapeutically potent anti-A $\beta$ antibodies (up to 1:10000 titer) were generated in APP/Tg mice using VLP based on papillomavirus [58,61], retrovirus [59], $\mathrm{Q} \beta$ bacteriophage [58,60]. $\mathrm{Q} \beta$-based vaccine comprising the $A \beta_{1-6}$ epitope (CAD106) covalently linked to VLPs [63] is currently in Phase II clinical trials conducted by Novartis. Report from Phase I trial on safety, tolerability and $A \beta$-specific antibody responses in a group of patients with mild to moderate AD following three subcutaneous injections of $50 \mu \mathrm{g}$ (cohort I) and $150 \mu \mathrm{g}$ (cohort II) CAD106 was encouraging and showed that adverse events were predominantly mild. Although CAD106 induced low titers of specific antibody with a 2-fold increase in cohorts II vs I, 16/24 and $18 / 22$ of subjects in cohort I and cohort II, respectively, responded to the vaccine $[64,65]$.

Our chimeric vaccine strategy described in this paper is different from VLP-based vaccines. First of all it is based on whole chimeric virus instead of non-replicative particles and therefore it could be used as either killed or live attenuated virus based vaccine. The use of chimeric influenza viruses whose backbone is widely used as a human influenza vaccine has the advantages of having quite well known antigenic properties in humans, of its immunogenicity being helped in humans by memory $\mathrm{T}$ cell responses against the backbone virus. More importantly, our strategy aimed to generate dual vaccine and test the feasibility of this approach.

Accordingly, we decided to take advantage from our previously developed plasmid-based reverse genetic technique [26] and generate a dual vaccine expressing the short B-cell epitope of amyloid within the HA of influenza virus. The HA and NA glycoproteins of influenza A viruses contain the major antigenic determinants of the virus responsible for the induction of neutralizing (protective) immune response. The appropriate mutations or insertions that may attenuate virus without compromising the immunogenicity of the vaccine allowed generating chimeric viruses (vectors) that can express heterologous polypeptides [66]. Because influenza viruses are potent inducers of antigen-specific $B$ and $\mathrm{T}$ cell immune responses [66] they can also be 
attractive candidates as delivery vectors for amyloid- $\beta$ Bcell epitope. In fact, previously it was shown that appropriate chimeric influenza viruses delivered heterologous small antigen (usually about 10-12 aa) into the host [67] and induced potent antibody [68] or cellular [69] immune responses specific to grafted peptide.

Here we generated and studied dual vaccines based on chimeric viruses, expressing $A \beta_{1-10}$ or $A \beta_{1-7}$ epitopes of $A \beta_{42}$. These $B$-cell epitopes of amyloid- $\beta$ were inserted between amino acids 171 and 172 of HA, while the other four antigenic sites of HA remained intact (Figure 1A). The WB analysis demonstrated that chimeric, but not WNT-WT virus expressed HA of correct size containing $A \beta_{1-10}$ (Figure $1 C$ ) or $A \beta_{1-7}$ (data not shown) peptides. Importantly, the insertion of $A \beta$ into HA did not change the capability of virus to infect host MDCK cells (Figure 2) or the conformation of the HA molecule (Figure 2 and 3).

Next we decided to analyze the immunogenic potency of the chimeric virus and compare it with that of wildtype influenza virus. Purified WSN-A $\beta_{1-10}$, WSN-A $\beta_{1-7}$, or WSN-WT viruses (Figure 1B and data not shown) has been used for preparation of inactivated vaccines that have been formulated into Th1 type adjuvant prior to immunization of experimental and control mice. We demonstrated that WSN-A $\beta_{1-10}$ was more immunogenic than WSN-A $\beta_{1-7}$ (Figure 4) and it induced the highest titers of anti-amyloid and anti-viral antibodies at $50 \mu \mathrm{g} /$ mouse dose (Figure 5). WSN-A $\beta_{1-10}$ induced as good anti-viral humoral immune responses as WSN-WT after 3-4 immunizations (Figure 5, 6). These results support our hypothesis that chimeric influenza virus could be an excellent delivery platform for $A \beta$ epitope, and at the same time provide $T$ helper cell help to $A \beta$ specific $B$ cells. Of note, using peptide, recombinant protein and DNA based epitope vaccines we showed that $A \beta_{1-11}$ region did not possess epitopes for $\mathrm{H} 2-\mathrm{b}$ and $\mathrm{H}-2 \mathrm{~d}$ mice $[20,23,25]$. More importantly, it was shown that Th epitope of $A \beta_{42}$ mapped to $C$-terminal region of this peptide [56]. Based on these data currently several companies are conducting Phase I/IIa studies with carriers fused with $\mathrm{N}$-terminal regions of amyloid [70,71].

The data represented above implied that a dual vaccine strategy is feasible since vaccinations of mice induced strong anti-viral and anti-amyloid humoral immune responses. At the same time these results did not demonstrate the therapeutic potency of anti-influenza and anti-A $\beta$ antibodies. To test that, we performed in vitro assessment using $\mathrm{HI}$ [29] and neurotoxicity $[24,32]$ assays routinely used in our laboratories. These analyses showed that chimeric virus maintained the ability to induce the production of (i) virus neutralizing antibodies that inhibited the hemagglutination of red cells by the both chimeric and wild-type viruses (Figure
9, 10); and (ii) anti-A $\beta$ antibodies that are binding to various $A \beta_{42}$ forms (Figure $8 \mathrm{~A}$ ) and inhibiting $A \beta_{42}$ fibrils- and oligomer-mediated toxicity of human neuroblastoma SH-SY5Y cells (Figure 8B). Data presented above suggest that anti-viral antibody could block viral infection while anti-A $\beta$ antibody could be an effective modulator of $A \beta_{42}$ aggregate formation regardless of the nature of the aggregated species. Indeed, anti- $A \beta$ antibody bind not only $A \beta_{42}$ fibrils and oligomers in vitro, but also $A \beta$ plaques present in brain sections of cortical AD tissue (Figure 7).

To our knowledge this is the first attempt for generation dual vaccine based on conventional seasonal Flu vaccine and therefore designed to protect the elderly from both $\mathrm{AD}$ and seasonal Flu infection. Annual administration of seasonal Flu vaccine is currently proposed, therefore it is important to study the persistence of anti-A $\beta$ antibodies and optimized schedule for vaccination with dual vaccine. However, in mice that are leaving in average 2.2-3.2 years it is not accurate testing annual vaccination strategy used for vaccination of elderly people. Thus, we are currently planning to study the doses, type of vaccine (killed or live attenuated), as well as schedule for vaccination in non-human primates, including aged animals with immunosenescence. The major complication connected with vaccination of elderly people is the poor response to the vaccines due to the immunosenescence. One possible strategy to counteract the immunosenescence is to recruit previously generated memory $\mathrm{T}$ cells produced during prior vaccinations and/or exposure to human pathogens. The majority of people already possess memory $\mathrm{T}$ cells specific for influenza due to yearly vaccinations and/or infection by virus. Thus, immunization of elderly people with our dual vaccine may in theory recruit memory $\mathrm{T}$ helper cells specific to influenza epitopes and induce rapid and potent anti-A $\beta$ antibody production, while continuing to boost anti-viral cellular and humoral responses. This hypothesis is the subject of studies in progress in our laboratories.

Another important aspect of a dual vaccine is related to the safety issues. Since the majority of people including children and elderly are vaccinated with influenza vaccine yearly and the safety of this vaccine is observed for a long period of time, the chance that the dual vaccine is safe is very high. Finally, we think that the availability of a safe dual vaccine will allow the treatment of pre-symptomatic people rather than AD patients. Based on both preclinical studies and the results from the AN1792 clinical trials [70,71] we may assume that early intervention in the disease process, pre-symptomatic if possible, is likely to be significantly more beneficial than attempting to intervene in the disease process after clinical diagnosis of the disease. 
In addition, early intervention is likely to significantly reduce the probability of adverse events in response to active immunization [14]. We believe that the recent breakthroughs in the development of biomarkers for AD provide a hope that patients can be accurately identified while they are still in the preclinical stages of AD [72-77], which should facilitate the usage of dual vaccines before extensive neuronal damage and cerebral amyloid angiopathy has occurred in the brain in the general population. At the same time it should be mentioned that many groups including us have not observed infiltration of autoreactive $\mathrm{T}$ cells (presumed Th1 response that likely occurred in AN1792 vaccinated patients) in the brains after immunizations of APP/Tg or wild-type mice with the original Schenk et al. protocol [2] or with other $A \beta$ vaccines (unless pertussis toxin widely used to induce brain $\mathrm{T}$ cell penetration in experimental autoimmune encephalomyelitis have been co-administered [78]). Thus, obviously only clinical trials may help us to conclude that any epitope vaccine including our chimeric flu vaccine is safe and do not induce harmful proinflammatory $\mathrm{T}$ cell responses in vaccinated $\mathrm{AD}$ patients.

\section{Acknowledgements}

Grant support: This work was supported by funding from NIH (NS-057395, AG-20241 and NS-50895) Alzheimer's Association (IIRG 07-283140). HD and NM were supported by NIA training grant AG000096. Additional support for AD case tissues was provided by University of California, Irvine Alzheimer's Disease Research Center Grant P50 AG16573.

\section{Author details \\ 'Department of Molecular Immunology, Institute for Molecular Medicine, Huntington Beach, CA 92647, USA. ${ }^{2}$ University of California, Irvine, Institute for Memory Impairments and Neurological Disorders, Irvine, CA 92697, USA. ${ }^{3}$ Department of Microbiology, Mount Sinai School of Medicine, New York, NY 10029 USA. ${ }^{4}$ Department of Microbiology and Immunology, University of Rochester, Rochester, NY 14642, USA. ${ }^{5}$ Global Health and Emerging Pathogens Institute, Mount Sinai School of Medicine, New York, NY 10029, USA. ${ }^{6}$ Department of Medicine, Division of Infection Diseases, Mount Sinai School of Medicine, New York, NY 10029, USA.}

\section{Authors' contributions}

HD contributed substantially in design of study, performed the immunization of mice, carried out immunoassays (ELISA, Dot Blot, Neurotoxicity assay). He participated in analyses and interpretation of data. He drafted the manuscript. AG has been involved in analyses and interpretation of data and statistical analysis. She helped to draft the manuscript. RC participated in preparation of chimeric viruses, purification of viral proteins and performing of hemagglutination inhibition assays. DZ cloned, generated, and characterized chimeric viruses. IP analyzed binding of antisera to $A B$ plaques in brain tissue from an $A D$ case. NM participated in immunization of mice and analyzed antibody responses using ELISA. LMS generated and characterized chimeric viruses, performed hemagglutination inhibition assays and participated in purification of chimeric viruses. RAA participated in analyses and interpretation of data. AGS helped to troubleshoot difficulties connected with experiments, helped to draft the manuscript, revised it critically for important intellectual content. MGA conceived the study, mentored primary authors, helped to analyze the data and make conclusions, prepared final version of manuscript. All authors read and approved the final manuscript.
}

\section{Declaration of competing interests}

Authors declare that they have no competing interests. Dr. García-Sastre is named inventor of a patent filed through Mount Sinai School of Medicine that is related to the generation of recombinant influenza A viruses from plasmid DNA.

Received: 12 May 2011 Accepted: 1 August 2011

Published: 1 August 2011

\section{References}

1. Price DL, Sisodia SS: Cellular and molecular biology of Alzheimer's disease and animal models. Annu Rev Med 1994, 45:435-446.

2. Schenk D, Barbour R, Dunn W, Gordon G, Grajeda H, Guido T, Hu K, Huang J, Johnson-Wood K, Khan K, et al: Immunization with amyloid-beta attenuates Alzheimer-disease-like pathology in the PDAPP mouse [see comments]. Nature 1999, 400:173-177.

3. Morgan D, Diamond DM, Gottschall PE, Ugen KE, Dickey C, Hardy J, Duff K, Jantzen P, DiCarlo G, Wilcock D, et al: A beta peptide vaccination prevents memory loss in an animal model of Alzheimer's disease. Nature 2000, 408:982-985

4. Janus C, Pearson J, McLaurin J, Mathews PM, Jiang Y, Schmidt SD, Chishti MA, Horne P, Heslin D, French J, et al: A beta peptide immunization reduces behavioural impairment and plaques in a model of Alzheimer's disease. Nature 2000, 408:979-982.

5. Bard F, Cannon C, Barbour R, Burke RL, Games D, Grajeda H, Guido T, Hu K, Huang J, Johnson-Wood K, et al: Peripherally administered antibodies against amyloid beta-peptide enter the central nervous system and reduce pathology in a mouse model of Alzheimer disease. Nat Med 2000, 6:916-919.

6. Dodart JC, Bales KR, Gannon KS, Greene SJ, DeMattos RB, Mathis C, DeLong CA, Wu S, Wu X, Holtzman DM, Paul SM: Immunization reverses memory deficits without reducing brain Abeta burden in Alzheimer's disease model. Nat Neurosci 2002, 5:452-457.

7. Wilcock DM, Rojiani A, Rosenthal A, Levkowitz G, Subbarao S, Alamed J, Wilson D, Wilson N, Freeman MJ, Gordon MN, Morgan D: Passive amyloid immunotherapy clears amyloid and transiently activates microglia in a transgenic mouse model of amyloid deposition. J Neurosci 2004, 24:6144-6151.

8. Nicoll JA, Wilkinson D, Holmes C, Steart P, Markham H, Weller RO: Neuropathology of human Alzheimer disease after immunization with amyloid-beta peptide: a case report. Nat Med 2003, 9:448-452.

9. Masliah E, Hansen L, Adame A, Crews L, Bard F, Lee C, Seubert P, Games D, Kirby $L$, Schenk D: Abeta vaccination effects on plaque pathology in the absence of encephalitis in Alzheimer disease. Neurology 2005, 64:129-131.

10. Hock C, Konietzko U, Streffer JR, Tracy J, Signorell A, Muller-Tillmanns B, Lemke U, Henke K, Moritz E, Garcia E, et al: Antibodies against betaAmyloid Slow Cognitive Decline in Alzheimer's Disease. Neuron 2003, 38:547-554.

11. Nicoll JA, Barton E, Boche D, Neal JW, Ferrer I, Thompson P, Vlachouli C, Wilkinson D, Bayer A, Games D, et al: Abeta species removal after abeta42 immunization. J Neuropathol Exp Neurol 2006, 65:1040-1048.

12. Gilman S, Koller M, Black RS, Jenkins L, Griffith SG, Fox NC, Eisner L, Kirby L, Rovira MB, Forette F, Orgogozo JM: Clinical effects of Abeta immunization (AN1792) in patients with AD in an interrupted trial. Neurology 2005, 64:1553-1562.

13. Holmes C, Boche D, Wilkinson D, Yadegarfar G, Hopkins V, Bayer A, Jones RW, Bullock R, Love S, Neal JW, et al: Long-term effects of Abeta42 immunization in Alzheimer's disease: follow-up of a randomised, placebo-controlled phase I trial. Lancet 2008, 372:216-223.

14. Ferrer I, Rovira MB, Guerra MLS, Rey MJ, Costa-Jussa F: Neuropathology and pathogenesis of encephalitis following amyloid-beta immunization in Alzheimer's disease. Brain Pathol 2004, 14:11-20.

15. Orgogozo JM, Gilman S, Dartigues JM, Laurent B, Puel M, Kirby LC, Jouanny $P$, Dubois B, Eisner L, Flitman $S$, et al: Subacute meningoencephalitis in a subset of patients with $A D$ after Abeta42 immunization. Neurology 2003, 61(1):46-54.

16. Patton RL, Kalback WM, Esh CL, Kokjohn TA, Van Vickle GD, Luehrs DC Kuo YM, Lopez J, Brune D, Ferrer I, et al: Amyloid-beta peptide remnants in AN-1792-immunized Alzheimer's disease patients: a biochemical analysis. Am J Pathol 2006, 169:1048-1063. 
17. Bayer AJ, Bullock R, Jones RW, Wilkinson D, Paterson KR, Jenkins L, Millais $S B$, Donoghue $S$ : Evaluation of the safety and immunogenicity of synthetic Abeta42 (AN1792) in patients with AD. Neurology 2005, 64:94-101.

18. Chackerian B, Lowy DR, Schiller JT: Conjugation of a self-antigen to papillomavirus-like particles allows for efficient induction of protective autoantibodies. J Clin Invest 2001, 108:415-423.

19. Abbas AK, Lohr J, Knoechel B, Nagabhushanam V: T cell tolerance and autoimmunity. Autoimmun Rev 2004, 3:471-475.

20. Agadjanyan MG, Ghochikyan A, Petrushina I, Vasilevko V, Movsesyan N, Mkrtichyan M, Saing T, Cribbs DH: Prototype Alzheimer's disease vaccine using the immunodominant $B$ cell epitope from beta-amyloid and promiscuous T cell epitope pan HLA DR-binding peptide. J Immunol 2005, 174:1580-1586.

21. Ghochikyan A, Mkrtichyan M, Petrushina I, Movsesyan N, Karapetyan A, Cribbs DH, Agadjanyan MG: Prototype Alzheimer's disease epitope vaccine induced strong Th2-type anti-Abeta antibody response with Alum to Quil A adjuvant switch. Vaccine 2006, 24:2275-2282.

22. Davtyan H, Mkrtichyan M, Movsesyan N, Petrushina I, Mamikonyan G, Cribbs DH, Agadjanyan MG, Ghochikyan A: DNA prime-protein boost increased the titer, avidity and persistence of anti-Abeta antibodies in wild-type mice. Gene Ther 2010, 17:261-271.

23. Petrushina I, Ghochikyan A, Mktrichyan M, Mamikonyan G, Movsesyan N, Davtyan H, Patel A, Head E, Cribbs DH, Agadjanyan MG: Alzheimer's Disease Peptide Epitope Vaccine Reduces Insoluble But Not Soluble/ Oligomeric A\{beta\} Species in Amyloid Precursor Protein Transgenic Mice. J Neurosci 2007, 27:12721-12731.

24. Mamikonyan G, Necula M, Mkrtichyan M, Ghochikyan A, Petrushina I, Movsesyan N, Mina E, Kiyatkin A, Glabe C, Cribbs DH, Agadjanyan MG: AntiAbeta 1-11 antibody binds to different beta-amyloid species, inhibits fibril formation, and disaggregates preformed fibrils, but not the most toxic oligomers. J Biol Chem 2007, , 282: 22376-22386.

25. Movsesyan N, Ghochikyan A, Mkrtichyan M, Petrushina I, Davtyan H, Olkhanud PB, Head E, Biragyn A, Cribbs DH, Agadjanyan MG: Reducing ADlike pathology in 3xTg-AD mouse model by DNA epitope vaccine- a novel immunotherapeutic strategy. PLOS ONE 2008, 3:e21-24.

26. Schickli JH, Flandorfer A, Nakaya T, Martinez-Sobrido L, Garcia-Sastre A, Palese P: Plasmid-only rescue of influenza $A$ virus vaccine candidates. Philos Trans R Soc Lond B Biol Sci 2001, 356:1965-1973.

27. Fodor E, Devenish L, Engelhardt OG, Palese P, Brownlee GG, Garcia-Sastre A: Rescue of influenza A virus from recombinant DNA. J Virol 1999, 73:9679-9682.

28. Nistal-Villan E, Gack MU, Martinez-Delgado G, Maharaj NP, Inn KS, Yang H, Wang R, Aggarwal AK, Jung JU, Garcia-Sastre A: Negative role of RIG-I serine 8 phosphorylation in the regulation of interferon-beta production. $J$ Biol Chem 2010, 285:20252-20261.

29. Wang S, Parker C, Taaffe J, Solorzano A, Garcia-Sastre A, Lu S: Heterologous HA DNA vaccine prime-inactivated influenza vaccine boost is more effective than using DNA or inactivated vaccine alone in eliciting antibody responses against $\mathrm{H} 1$ or $\mathrm{H} 3$ serotype influenza viruses. Vaccine 2008, 26:3626-3633.

30. Dickey CA, Morgan DG, Kudchodkar S, Weiner DB, Bai Y, Cao C, Gordon MN, Ugen KE: Duration and specificity of humoral immune responses in mice vaccinated with the Alzheimer's disease-associated beta-amyloid 1-42 peptide. DNA Cell Biol 2001, 723-729.

31. Cribbs DH, Agadjanyan MG: Immunotherapy for Alzheimer's Disease Potential Problems and Possible Solutions. Current Immunology Reviews 2005, 1:139-155

32. Wang XP, Zhang JH, Wang YJ, Feng $Y$, Zhang $X$, Sun XX, Li JL, Du XT, Lambert MP, Yang SG, et al: Conformation-dependent single-chain variable fragment antibodies specifically recognize beta-amyloid oligomers. FEBS Lett 2009, 583:579-584.

33. Martínez-Sobrido L, Garcia-Sastre A: Recombinant influenza virus vectors. Future Virology 2007, 2:401-416.

34. Bard F, Barbour R, Cannon C, Carretto R, Fox M, Games D, Guido T, Hoenow K, Hu K, Johnson-Wood K, et al: Epitope and isotype specificities of antibodies to beta-amyloid peptide for protection against Alzheimer's disease-like neuropathology. Proc Natl Acad Sci USA 2003, 100:2023-2028.

35. Cribbs DH, Ghochikyan A, Tran M, Vasilevko V, Petrushina I, Sadzikava N Kesslak P, Kieber-Emmons T, Cotman CW, Agadjanyan MG: Adjuvant- dependent modulation of Th1 and Th2 responses to immunization with beta-amyloid. Int Immunol 2003, 15:505-514.

36. Petrushina I, Tran M, Sadzikava N, Ghochikyan A, Vasilevko V, Agadjanyan MG, Cribbs DH: Importance of IgG2c isotype in the immune response to b-amyloid in APP/Tg mice. Neurosci Letters 2003, 338:5-8.

37. McLaurin J, Cecal R, Kierstead ME, Tian X, Phinney AL, Manea M, French JE, Lambermon MH, Darabie AA, Brown ME, et al: Therapeutically effective antibodies against amyloid-beta peptide target amyloid-beta residues 410 and inhibit cytotoxicity and fibrillogenesis. Nat Med 2002, 8:1263-1269.

38. Lemere CA, Maron R, Selkoe DJ, Weiner HL: Nasal vaccination with betaamyloid peptide for the treatment of Alzheimer's disease. DNA Cell Biol 2001, 20:705-711.

39. Town T, Tan J, Sansone N, Obregon D, Klein T, Mullan M: Characterization of murine immunoglobulin $\mathrm{G}$ antibodies agaisnt human amyloid-b 1-42. Neuroscience Letters 2001, 307:101-104.

40. Lee M, Bard F, Johnson-Wood K, Lee C, Hu K, Griffith SG, Black RS, Schenk D, Seubert P: Abeta42 immunization in Alzheimer's disease generates Abeta N-terminal antibodies. Ann Neurol 2005, 58:430-435.

41. Monsonego A, Maron R, Zota V, Selkoe DJ, Weiner HL: Immune hyporespobnsivness to amyloid b-peptide in amyloid precursor protein transgenic mice: implications for the pathogenesis and treatment of Alzheimer's disease. Proc Nat Acad Sci USA 2001, 98:10273-10278.

42. Schenk D: Opinion: Amyloid-beta immunotherapy for Alzheimer's disease: the end of the beginning. Nat Rev Neurosci 2002, 3:824-828.

43. Gelinas DS, DaSilva K, Fenili D, St George-Hyslop P, McLaurin J: Immunotherapy for Alzheimer's disease. Proc Natl Acad Sci USA 2004, 101(Suppl 2):14657-14662.

44. Levine MM, Sztein MB: Vaccine development strategies for improving immunization: the role of modern immunology. Nat Immunol 2004, 5:460-464

45. Dodel RC, Hampel H, Du Y: Immunotherapy for Alzheimer's disease. Lancet Neurol 2003, 2:215-220.

46. Dodart JC, Bales KR, Paul SM: Immunotherapy for Alzheimer's disease: will vaccination work? Trends Mol Med 2003, 9:85-87.

47. Monsonego A, Weiner HL: Immunotherapeutic approaches to Alzheimer's disease. Science 2003, 302:834-838.

48. Heppner FL, Gandy S, McLaurin J: Current Concepts and Future Prospects for Alzheimer Disease Vaccines. J Alz Dis Ass Disord 2004, 18:38-43.

49. Weiner HL, Selkoe DJ: Inflammation and therapeutic vaccination in CNS diseases. Nature 2002, 420:879-884.

50. Broytman O, Malter JS: Anti-Abeta: The good, the bad, and the unforeseen. J Neurosci Res 2004, 75:301-306.

51. Holtzman DM, Bales KR, Paul SM, DeMattos RB: Abeta immunization and anti-Abeta antibodies: potential therapies for the prevention and treatment of Alzheimer's disease. Adv Drug Deliv Rev 2002, 54:1603-1613.

52. Schenk D, Hagen $M$, Seubert $P$ : Current progress in beta-amyloid immunotherapy. Curr Opin Immunol 2004, 16:599-606.

53. Golde TE, Das P, Levites Y: Quantitative and mechanistic studies of abeta immunotherapy. CNS Neurol Disord Drug Targets 2009, 8:31-49.

54. Morgan D: The role of microglia in antibody-mediated clearance of amyloid-beta from the brain. CNS Neurol Disord Drug Targets 2009, 8:7-15.

55. Miller DL, Currie JR, Mehta PD, Potemska A, Hwang YW, Wegiel J: Humoral immune response to fibrillar beta-amyloid peptide. Biochemistry 2003, 42(40):11682-11692.

56. Monsonego A, Zota V, Karni A, Krieger Jl, Bar-Or A, Bitan G, Budson AE, Sperling R, Selkoe D, Weiner HL: Increased T cell reactivity to amyloid beta protein in older humans and patients with Alzheimer disease. J Clin Invest 2003, 112(3):415-422.

57. Lemere CA, Masliah E: Can Alzheimer disease be prevented by amyloidbeta immunotherapy? Nat Rev Neurol 2010, 6:108-119.

58. Chackerian B, Rangel M, Hunter Z, Peabody DS: Virus and virus-like particle-based immunogens for Alzheimer's disease induce antibody responses against amyloid-beta without concomitant $\mathrm{T}$ cell responses. Vaccine 2006, 24:6321-6331.

59. Bach P, Tschape JA, Kopietz F, Braun G, Baade JK, Wiederhold KH, Staufenbiel M, Prinz M, Deller T, Kalinke U, et al: Vaccination with Abetadisplaying virus-like particles reduces soluble and insoluble cerebral Abeta and lowers plaque burden in APP transgenic mice. J Immunol 2009, 182:7613-7624.

60. Li QY, Gordon MN, Chackerian B, Alamed J, Ugen KE, Morgan D: Virus-like peptide vaccines against Abeta $\mathrm{N}$-terminal or $\mathrm{C}$-terminal domains 
reduce amyloid deposition in APP transgenic mice without addition of adjuvant. J Neuroimmune Pharmacol 2010, 5:133-142.

61. Zamora E, Handisurya A, Shafti-Keramat S, Borchelt D, Rudow G, Conant K, Cox C, Troncoso JC, Kirnbauer R: Papillomavirus-like particles are an effective platform for amyloid-beta immunization in rabbits and transgenic mice. J Immunol 2006, 177:2662-2670.

62. Mantile F, Basile C, Cicatiello V, De Falco D, Caivano A, De Berardinis P, Prisco A: A multimeric immunogen for the induction of immune memory to beta-amyloid. Immunol Cell Biol 2011, 89:604-609.

63. Jennings GT, Bachmann MF: The coming of age of virus-like particle vaccines. Biol Chem 2008, 389:521-536.

64. Winblad BG, Minthon L, Floesser A, Imbert G, Dumortier T, He Y, Maguire P, Karlsson M, Ostlund H, Lundmark J, et al: Results of the first-in-man study with the active Abeta immunotherapy CAD106 in Alzheimer's patients. Alzheimer's \& Dementia: Journal of Alzheimer's Association 2009, 5:113-114.

65. Orgogozo J-M, Graf A, Staufenbiel M, Andreasen N, Winblad B: Active immunization against amyloid: Ab1-6/Qb (CAD106) removes b-amyloid from the brain, does not induce Ab-reactive T cells and is well tolerated ina first-in-man study in AD. Book Active immunization against amyloid: $A b 1-6 / Q b$ (CAD106) removes b-amyloid from the brain, does not induce Abreactive $T$ cells and is well tolerated ina first-in-man study in $A D$ (Editor ed. ^eds.) City 2011.

66. Garcia-Sastre A: Negative-strand RNA viruses: applications to biotechnology. Trends Biotechnol 1998, 16:230-235.

67. Li SQ, Schulman JL, Moran T, Bona C, Palese P: Influenza A virus transfectants with chimeric hemagglutinins containing epitopes from different subtypes. J Virol 1992, 66:399-404.

68. Li S, Polonis V, Isobe H, Zaghouani H, Guinea R, Moran T, Bona C, Palese P: Chimeric influenza virus induces neutralizing antibodies and cytotoxic $T$ cells against human immunodeficiency virus type 1. J Virol 1993, 67:6659-6666.

69. Efferson CL, Schickli J, Ko BK, Kawano K, Mouzi S, Palese P, Garcia-Sastre A, loannides CG: Activation of tumor antigen-specific cytotoxic $T$ lymphocytes (CTLs) by human dendritic cells infected with an attenuated influenza A virus expressing a CTL epitope derived from the HER-2/neu proto-oncogene. J Virol 2003, 77:7411-7424.

70. Agadjanyan MG, Cribbs DH: Active and passive Abeta-immunotherapy: preclinical and clinical studies and future directions: part I. CNS Neurol Disord Drug Targets 2009, 8:1-6.

71. Cribbs DH, Agadjanyan MG: Active and passive Abeta-immunotherapy: preclinical and clinical studies and future directions: part II. CNS Neurol Disord Drug Targets 2009, 8:82-87.

72. Bacskai BJ, Frosch MP, Freeman SH, Raymond SB, Augustinack JC, Johnson KA, Irizarry MC, Klunk WE, Mathis CA, Dekosky ST, et al: Molecular imaging with Pittsburgh Compound B confirmed at autopsy: a case report. Arch Neurol 2007, 64:431-434.

73. Bateman RJ, Wen G, Morris JC, Holtzman DM: Fluctuations of CSF amyloidbeta levels: implications for a diagnostic and therapeutic biomarker. Neurology 2007, 68:666-669.

74. Fagan AM, Roe CM, Xiong C, Mintun MA, Morris JC, Holtzman DM: Cerebrospinal fluid tau/beta-amyloid(42) ratio as a prediction of cognitive decline in nondemented older adults. Arch Neurol 2007, 64:343-349.

75. Graff-Radford NR, Crook JE, Lucas J, Boeve BF, Knopman DS, Ivnik RJ, Smith GE, Younkin LH, Petersen RC, Younkin SG: Association of low plasma Abeta42/Abeta40 ratios with increased imminent risk for mild cognitive impairment and Alzheimer disease. Arch Neurol 2007, 64:354-362.

76. Kauwe JS, Jacquart S, Chakraverty S, Wang J, Mayo K, Fagan AM, Holtzman DM, Morris JC, Goate AM: Extreme cerebrospinal fluid amyloid beta levels identify family with late-onset Alzheimer's disease presenilin 1 mutation. Ann Neurol 2007, 61:446-453.

77. Simonsen AH, McGuire J, Hansson O, Zetterberg H, Podust VN, Davies HA, Waldemar G, Minthon L, Blennow K: Novel panel of cerebrospinal fluid biomarkers for the prediction of progression to Alzheimer dementia in patients with mild cognitive impairment. Arch Neurol 2007, 64:366-370.

78. Hofstetter HH, Shive CL, Forsthuber TG: Pertussis toxin modulates the immune response to neuroantigens injected in incomplete Freund's adjuvant: induction of Th1 cells and experimental autoimmune encephalomyelitis in the presence of high frequencies of Th2 cells. J Immunol 2002, 169:117-125. doi:10.1186/1479-5876-9-127

Cite this article as: Davtyan et al:: The immunological potency and therapeutic potential of a prototype dual vaccine against influenza and Alzheimer's disease. Journal of Translational Medicine 2011 9:127.

\section{Submit your next manuscript to BioMed Central and take full advantage of:}

- Convenient online submission

- Thorough peer review

- No space constraints or color figure charges

- Immediate publication on acceptance

- Inclusion in PubMed, CAS, Scopus and Google Scholar

- Research which is freely available for redistribution 